\title{
Depositional environments and hydrocarbon potential of the Middle Jurassic Los Molles Formation, Neuquén Basin, Argentina: palynofacies and organic geochemical data
}

\author{
Marcelo A. Martínez ${ }^{1}$, Mercedes B. Prámparo², Mirta E. Quattrocchio ${ }^{1}$, Carlos A. Zavala ${ }^{3}$
}

\footnotetext{
CONICET (Consejo Nacional de Investigaciones Cientificas y Técnicas)-INGEOSUR (Instituto Geológico del Sur), Universidad Nacional del Sur, Departamento de Geología, San Juan 670, 8000, Bahía Blanca, Argentina. martinez@criba.edu.ar; mquattro@criba.edu.ar

2 CONICET. CRICYT (Centro Regional de Investigaciones Cientificas y Tecnológicas), IANIGLA (Instituto Argentino de Nivología, Glaciología y Ciencias Ambientales), Unidad de Paleopalinología, C.C. 330, 5500, Mendoza, Argentina. mprampar@lab.cricyt.edu.ar

3 Universidad Nacional del Sur, Departamento de Geología, San Juan 670. GCS Argentina, Haití 123, 8000, Bahía Blanca, Argentina. czavala@uns.edu.ar
}

\begin{abstract}
A multidisciplinary analysis of palynofacies in a sequence-stratigraphical framework, TOC (total organic carbon) and TAI (thermal alteration index) analyses, has been applied to outcrop samples of the uppermost Los Molles Formation (Middle Jurassic), Neuquén Basin, Argentina, in order to characterise the palaeoenvironmental and palaeoclimatic conditions during the deposition of this unit. Five types of palynofacies ( -1 to P-5) have been identified and are interpreted to indicate a restricted marine to inner neritic environment. In P-1 and P-4, a marine environment close to the terrestrial source area with moderate oxidizing conditions and energy, is suggested. In P-2, the assemblage of freshwater algae, acritarchs and prasinophytes suggest a marginal marine environment influenced by fluvial discharge. In P-3, the marine microplankton content reflects conditions ranging from a marginal-marine (sub-normal salinity) to an inner neritic environment. In P-5, a dysoxic marine environment (probably marginal) is suggested. Warm and relatively humid (abundance of Cheirolepidiaceae in association with Araucariaceae) and locally humid (presence of swamps or ponds, on the alluvial plains) conditions are inferred. TOC content (65\% of the analyzed samples reach TOC values over $1 \%$ ), TAI values ( 2 to $2+$, transitional between an immature phase and the window of liquid petroleum generation) and kerogen type (P-1, P-2 and P-5 show transitional characteristics between kerogen type II and III, while P-3 and P-4 show characteristics of kerogen type III and occasionally type IV), suggest that, in the studied area, the Los Molles Formation has some hydrocarbon potential. However, kerogen state suggests that the anoxic-dysoxic conditions of the site of deposition were not optimum for its preservation.
\end{abstract}


RESUMEN. Ambientes depositacionales y potencial oleogenético de la Formación Los Molles, Jurásico Medio de la Cuenca Neuquina, Argentina: palinofacies y datos de geoquímica orgánica. El análisis multidisciplinario de las palinofacies, carbono orgánico total (COT) e índice de alteración térmica (IAT) en un contexto estratigráfico-secuencial ha sido llevado a cabo con muestras de afloramiento correspondientes a depósitos terminales de la Formación Los Molles, Jurásico Medio de la Cuenca Neuquina, Argentina, con el objeto de caracterizar las condiciones paleoambientales y paleoclimáticas imperantes durante la depositación de esta unidad. Han sido identificados cinco tipos de palinofacies (P-1 a P-5), interpretados como indicativos de ambientes marinos restringidos hasta nerítico internos. P-1 y P-4 sugieren ambientes marinos próximos al área de aporte continental, bajo condiciones de moderada energía y oxidación. En P-2, la asociación de algas dulceacuícolas, acritarcos y prasinofitas, sugiere un ambiente marino marginal influenciado por descarga fluvial. En P-3, el contenido de microplancton marino refleja condiciones marinas marginales (salinidad subnormal) hasta neríticas internas. En P-5, se sugiere un ambiente marino (probablemente marginal) y disóxico. La abundancia de Cheirolepidiaceae asociada a Aruacariaceae, sugiere condiciones de clima cálido-relativamente húmedo, localmente húmedo en torno a zonas pantanosas. El contenido de carbono orgánico total (el $65 \%$ de las muestras analizadas alcanza valores de COT superiores al 1\%), los valores de índice de alteración térmica (IAT entre 2 y $2+$, transicional entre fase inmadura y la ventana de generación de petróleo) y los tipos de querógeno determinados (P-1, P-2 y P-5 muestran características transicionales entre querógenos de tipo II y III, mientras que P-3 y P-4 se asocian a querógeno de tipo III y ocasionalmente de tipo IV), permiten sugerir que, en el área de estudio, la Formación Los Molles presenta cierto potencial oleogenético. Sin embargo, el estado del querógeno sugiere que las condiciones anóxico-disóxicas del ambiente depositacional no fueron las óptimas para su preservación.

Palabras claves: Palinofacies, Paleoambientes, Potencial oleogenético, Carbono orgánico total (COT), Jurásico Medio, Cuenca Neuquina, Argentina.

\section{Introduction}

Located at the southwestern part of South America, the Neuquén Basin is the main oil producing basin of Argentina. Its deposits include more than 7,000 m of continental and marine sediments, which accumulated during the Jurassic and Cretaceous. The Los Molles Formation (Lower to Middle Jurassic) constitutes the first marine unit above syn-rift continental deposits and includes hundreds of metres of ammonite-bearing black shales with intercalated turbidites (Burgess et al., 2000).

In this paper, samples of the uppermost Los Molles Formation (time equivalent to the shallow marine sandstone of the Lajas Formation) exposed in the central-western area of the Neuquén Basin were palynologically analyzed. Integration of lithofacies with palynofacies data within a sequencestratigraphic framework, were used to reconstruct the environments of deposition. A model suggesting the paleogeographic evolution of the uppermost Los Molles Formation, genetically related to a northward prograding coastal system, is proposed here.

The Los Molles Formation has been traditionally considered one of the hydrocarbon sources in the Jurassic units. It was assumed that the large quantities of gas accumulations at the center and periphery of the basin are related to the evolution of organic matter within this formation (Cruz et al., 2002).
In this contribution the sequence stratigraphic, palynofacies (transmited light and blue light fluorescence), thermal alteration index (TAI) and total organic carbon content (TOC) analyses were carried out constituting, the first multidisciplinary approach in the research of this formation.

The palynostratigraphic analysis (descriptions, illustrations and range charts) for the Los Molles Formation in the studied area were presented in Quattrocchio et al. (1996); García (1998); Martínez (1999) and Martínez et al. (2005). Aditional information about palynological data of the formation was presented in Martínez et al. (2005).

\section{Geological Setting and Stratigraphy}

The Jurassic section of the Neuquén Basin was deposited in a back-arc basin located in western central Argentina. It originated during latest Triassic times and was an important locus of sedimentation during the Jurassic and Early Cretaceous. The Early-Middle Jurassic Cuyo Group (also named 'Cuyano'; Groeber, 1946) represents the first major marine depositional episode after the basin configuration (Text-fig. 1). The Cuyo Group comprise deposits more than 2,500 $\mathrm{m}$ thick beginning with a transgressive event during the Hettangian-Pliensbachian stages, followed by regressive deposits developed until the middle Callovian (Zavala, 1996a). These regressive deposits consist of 


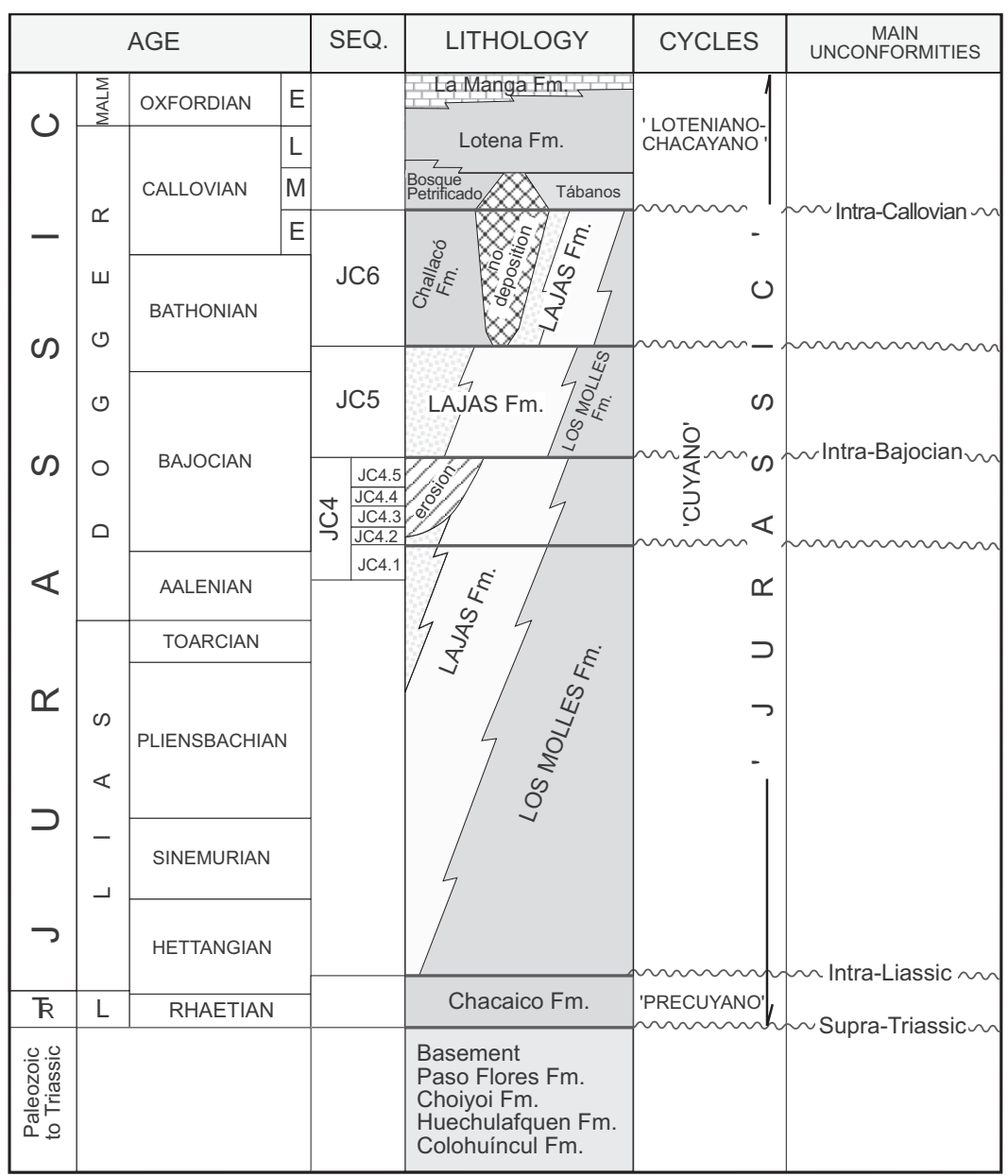

Text-fig. 1. Stratigraphic chart for the Jurasssic of the Neuquén Basin.

a prograding clastic section where, offshore fine-grained deposits of the Los Molles Formation (Weaver, 1931) with isolated turbidite intervals are progressively overlain by sandstones and conglomerates reflecting shallow marine to continental environments (Lajas Formation; Weaver, 1931; Gulisano et al., 1984; Hinterwimmer and Jáuregui, 1984; Zavala and González, 2001). The geochemical characterization of these deposits shows that the Los Molles Formation was probably accumulated in different isolated depocenters both in marine and lacustrine (no evidence presented here for lacustrine) settings (Zumberge, 1993).

Using paleontological data, Volkheimer (1973) suggested that the Los Molles Formation in the Sierra de Chacaico was deposited during the ToarcianAalenian to possibly the early Bajocian. From paly- nological data and ammonite fauna, Hinterwimmer and Jáuregui (1984) established an early Toarcian to late Toarcian-early Callovian age for these deposits in Barda Colorada (borehole), in the eastern part of the Neuquén Province.

The studied area is located in the central-western part of the Neuquén Basin (39 $10^{\circ}-39^{\circ} 21^{\prime} \mathrm{S}$ and $\left.69^{\circ} 39^{\prime}-70^{\circ} 25^{\prime} \mathrm{W}\right)$, close to the town of Zapala. Rock samples from five stratigraphical sections have been analyzed and respectively named Lohan Mahuida (119 $\mathrm{m}$ of the Los Molles Formation), Puente Picún Leufú (98.2 m), Puesto Policía (107.4 m), Los Molles $(74.8 \mathrm{~m})$ and Cerro Lotena $(50.5 \mathrm{~m})$ (Text-fig. 2).

The sequence stratigraphical analysis of the Los Molles Formation in the Neuquén Basin (Zavala 1993, 1996a, b) allows the recognition of two fourth 


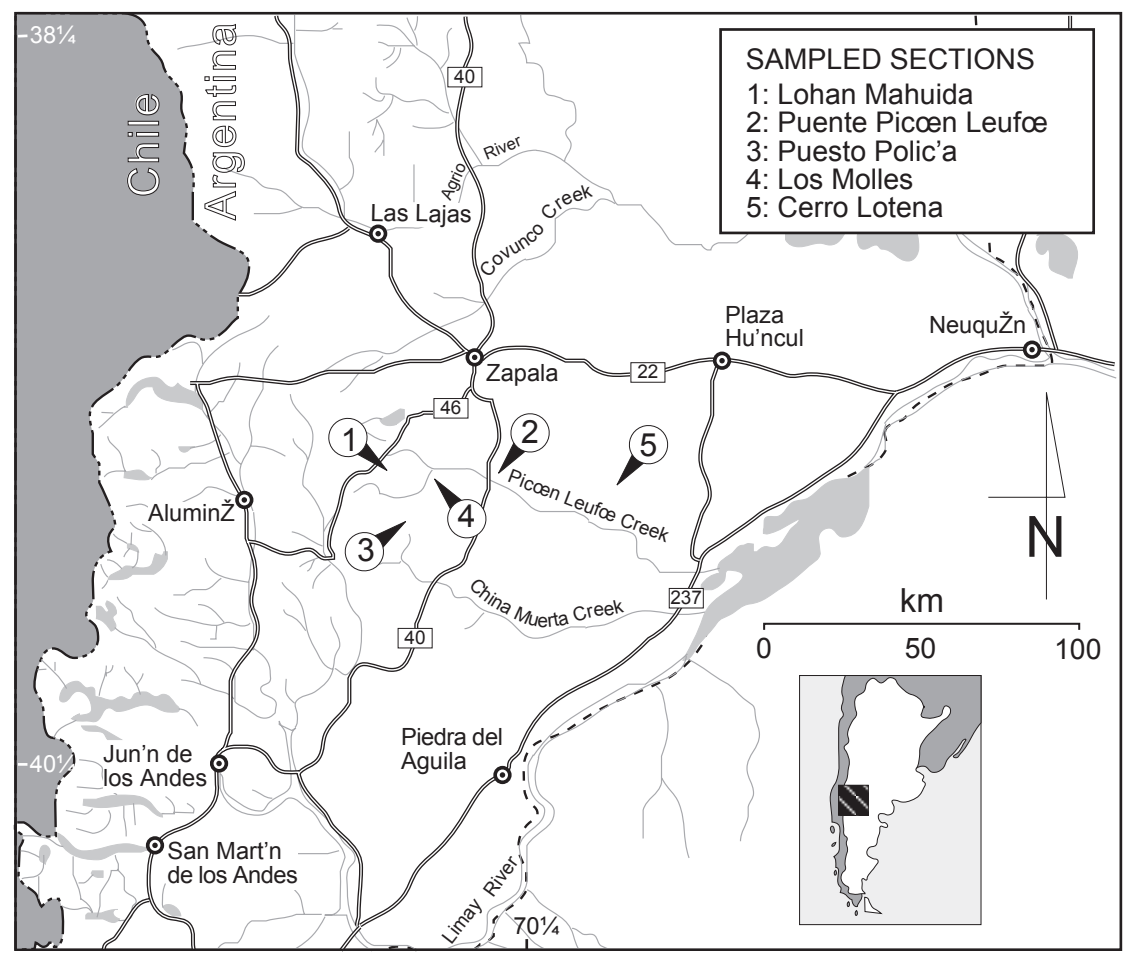

Text-fig. 2. Location map of the studied sections.

order depositional sequences (calibrated from ammonoid data) named JC4.1 and JC4.2 (Text-fig. 3), which show an internal organization into different system tracts. In the studied sections, sequence JC4.1 has not yielded any useful macrofossils; however Zavala (1996a) mentioned in equivalent sections of this sequence an association of ammonoids of the Puchenquia malarguensis and Pseudotoites singularis Assemblage Zones (Westermann and Riccardi, 1979). The upper levels of this sequence contain an ammonoid fauna assigned to the Emileia giebeli submicrostoma Assemblage Subzone (Westermann and Riccardi, 1979). The age of sequence JC4.1 ranges from late Aalenian to earliest Bajocian. Riccardi and Gulisano (1990) extended the lower limit of this sequence back into the latest Toarcian. The presence of Emileia sp. from the Emileia giebeli Assemblage Zone (Westermann and Riccardi, 1979) at $126 \mathrm{~m}$ from the base of Lohan Mahuida section suggests an early Bajocian Age for the JC4.2 sequence.

The palynoflora analyzed in this paper correlates with the Callialasporites 'complex' Biozone, $\mathrm{Ca}$ llialasporites trilobatus (late Aalenian-earliest Ba- jocian), Antulsporites saevus (early Bajocian) and Klukisporites labiatus (early Bajocian) Sub-biozones defined by Martínez (2002) for the same area. This biozonation was calibrated using ammonoid data and analyzed within a sequence stratigraphic framework. The suggested age for the Los Molles Formation in central-western Neuquén Basin is late Aalenian to early Bajocian.

\section{Materials and methods}

A total of 20 outcrop samples (mudstones and siltstones) of the Los Molles Formation were collected from five sections close to the town of Zapala. The samples were taken according to the different sedimentary environments and depositional units identified during field work (Table 1).

The samples were processed using standard palynological HCl-HF acid maceration techniques (Volkheimer and Melendi, 1976). After chemical removal of the mineral matrix a first slide of unsieved and unoxidised organic residue was made for palynofacies and related thermal maturation studies. Following Batten $(1981,1996)$ 


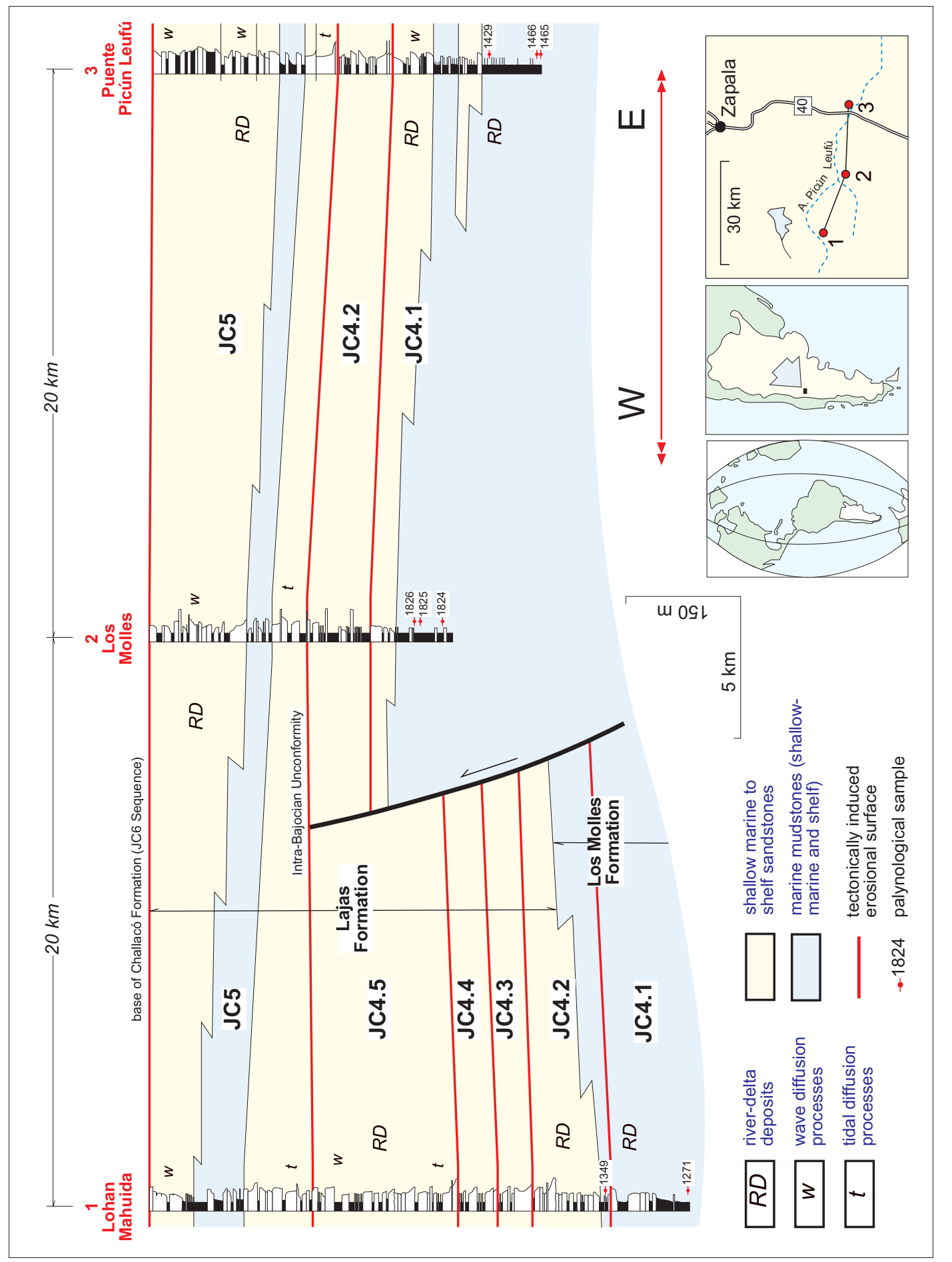

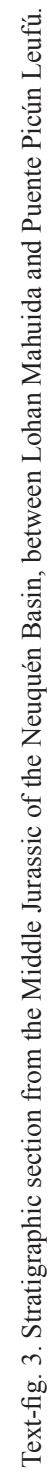


TABLE 1. DISTRIBUTION OF THE PALYNOLOGICAL SAMPLES IN EACH ANALYZED SECTION, WITH INDICATIONS OF LITHOFACIES, DEPOSITIONAL ENVIRONMENTS AND SEQUENCE UNITS.

\begin{tabular}{|c|c|c|c|c|}
\hline Sections & $\begin{array}{l}\text { Sample } \\
\text { number }\end{array}$ & $\begin{array}{c}m \text { above } \\
\text { base }\end{array}$ & Lithofacies & $\begin{array}{l}\text { Depositional environments } \\
\text { and sequence units }\end{array}$ \\
\hline \multirow{3}{*}{ Los Molles } & $1826 \bullet$ & 51 & \multirow{3}{*}{ medium grey mudstones } & \multirow{3}{*}{ Shelf (JC4.1-HST) } \\
\hline & $1825 \bullet$ & 37 & & \\
\hline & 1824 & 13 & & \\
\hline \multirow{8}{*}{ Puesto Policía } & $1796 \bullet$ & 105 & medium grey siltstones & \multirow{3}{*}{ Shelf (JC4.2-HST) } \\
\hline & $1795 \bullet$ & 85 & \multirow{7}{*}{ medium grey mudstones } & \\
\hline & 1794 & 70,2 & & \\
\hline & $1793 \bullet$ & 60,3 & & \multirow{5}{*}{$\begin{array}{l}\text { Shelf to lower delta front } \\
\text { (JC4.1-HST) }\end{array}$} \\
\hline & $1792 \bullet$ & 41 & & \\
\hline & $1791 \bullet$ & 26,5 & & \\
\hline & $1790 \bullet$ & 18 & & \\
\hline & $1789 \bullet$ & 3 & & \\
\hline \multirow{4}{*}{$\begin{array}{l}\text { Cerro } \\
\text { Lotena }\end{array}$} & 1749 & 49,5 & medium grey mudstones with land plant debris & \multirow{4}{*}{$\begin{array}{c}\text { Mouth bars of 'braided deltas' } \\
\text { (JC4.1-HST) }\end{array}$} \\
\hline & 1748 & 42 & medium grey mudstones & \\
\hline & 1747 & 34,5 & medium grey mudstones with land plant debris & \\
\hline & 1746 & 22,5 & \multirow{2}{*}{ medium grey mudstones } & \\
\hline \multirow{3}{*}{$\begin{array}{l}\text { Puente Picún } \\
\text { Leufú }\end{array}$} & $1429 \bullet$ & 45,8 & & \multirow{3}{*}{ Shelf (JC4.1-HST) } \\
\hline & $1466 \bullet$ & 19 & medium brown mudstones with bivalves & \\
\hline & 1465 & 3 & medium brown mudstones & \\
\hline \multirow{2}{*}{$\begin{array}{l}\text { Lohan } \\
\text { Mahuida }\end{array}$} & 1349 & 111 & medium grey siltstones & Distal bars (JC4.2-TST) \\
\hline & 1271 & 0 & light brown siltstones with land plant debris & Shelf (JC4.1-HST) \\
\hline
\end{tabular}

- samples with palynomorphs

and Batten and Morrison (1983) a second stage in the preparation procedure is to submit the residue to brief ultrasonic and/or oxidative treatment (not more than two minutes). After this cleaning up process, a second slide was mounted to determine the nature of the amorphous matter, because if it is derived from land plants it is more readily removed by oxidation than if it is of algal/bacterial origin. The mounting medium used to prepare the palynological slides was NOA 61 (Northland Products Incorporated, USA), which appears to be the best for fluorescence work because it provides a dark green background.

The palynological slides are housed in the Laboratory of Palynology, Universidad Nacional del Sur, Bahía Blanca, Argentina, under the name UNSP followed by the denomination of each study section: LM (Lohan Mahuida), PL (Puente Picún Leufú), PP (Puesto Policía), M (Los Molles) and CL (Cerro Lotena). The samples were studied with an OLYMPUS BH 2 and with blue light fluorescence microscopy for organic matter analyses; the photomicrographs of selected palynomorphs were taken with an OLYMPUS Digital camera (Plate 1). Specimen locations are referred to England Finder coordinates (e.g., UNSP PP 1795a: D25/1).

Description of lithofacies, depositional sequences and paleoenvironmental interpretations of the sections has been previously provided by Zavala (1993).

\subsection{Palynofacies Analysis}

The palynofacies analysis was carried out following Tyson (1995) and Batten (1996), distinguishing four types of palynological matter (PM), comprising structured (palynomorphs, translucent phytoclasts and opaque phytoclasts) and structureless organic matter, commonly referred to as amorphous organic matter (AOM). A visual estimation of the relative abundances of palynological organic components (semi-quantitative approach) was also carried out, under 20X magnification, and expressed as percentages of PM (Table 2). 


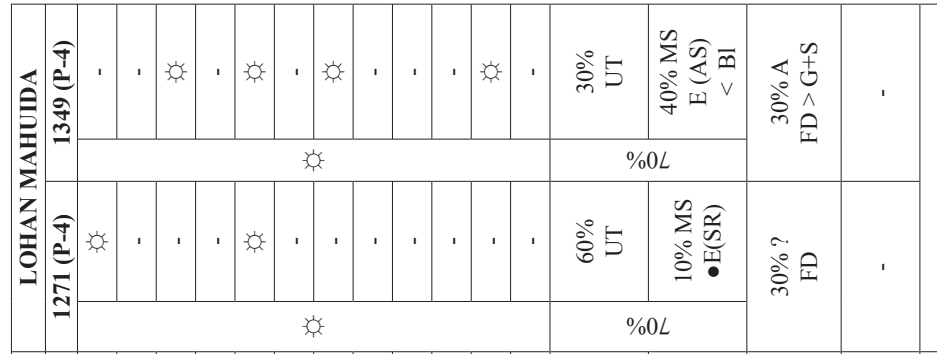

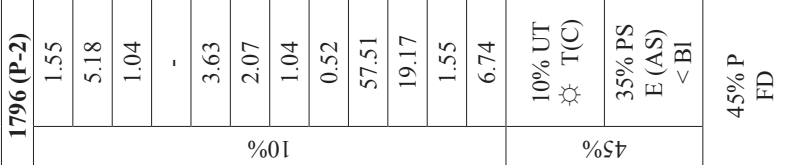

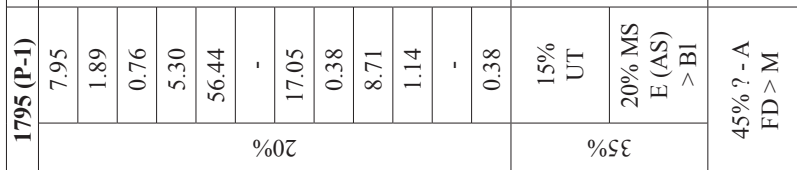

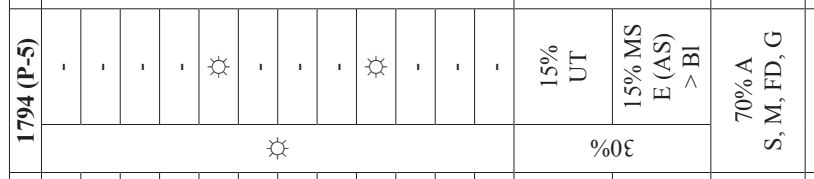

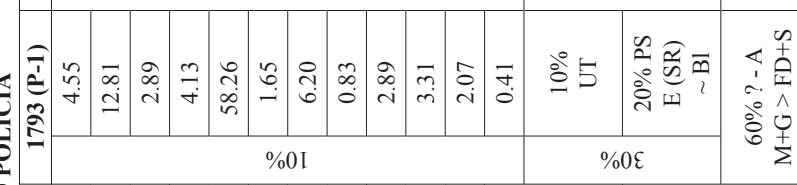

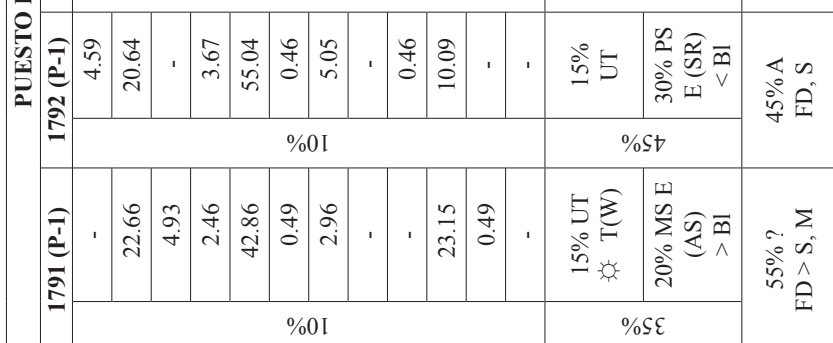

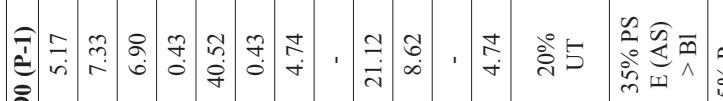

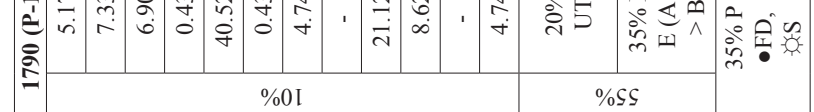

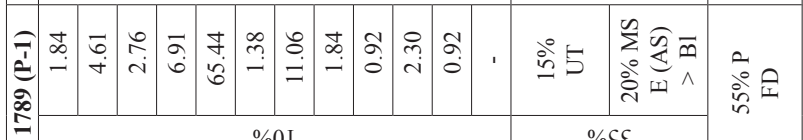

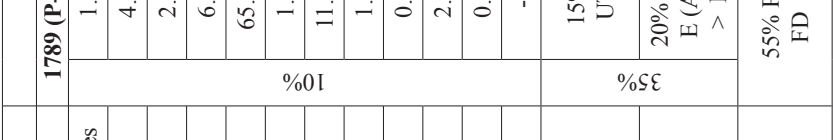

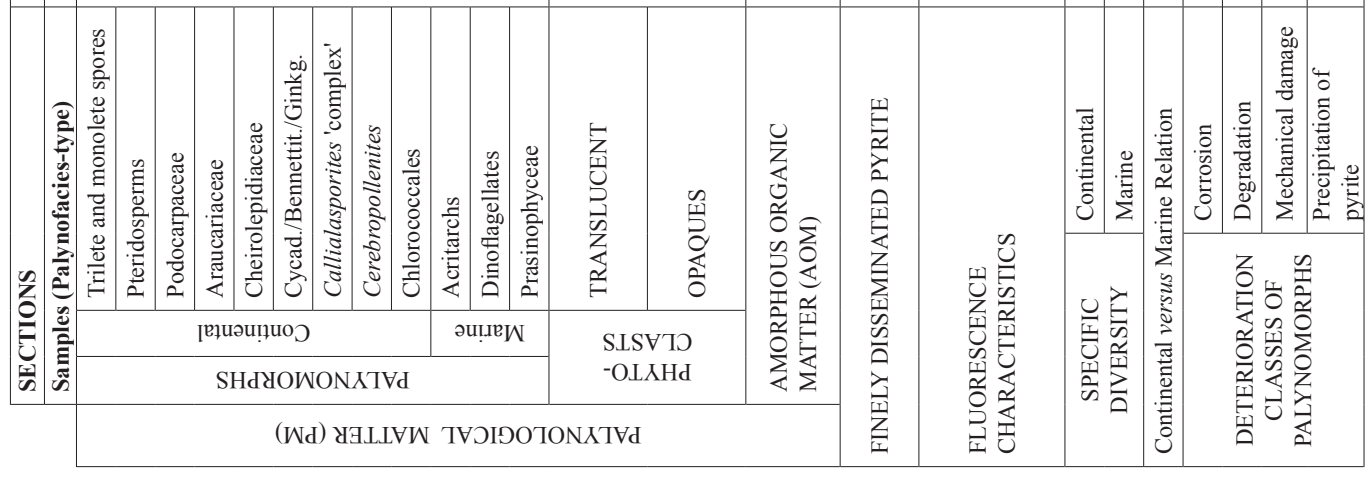




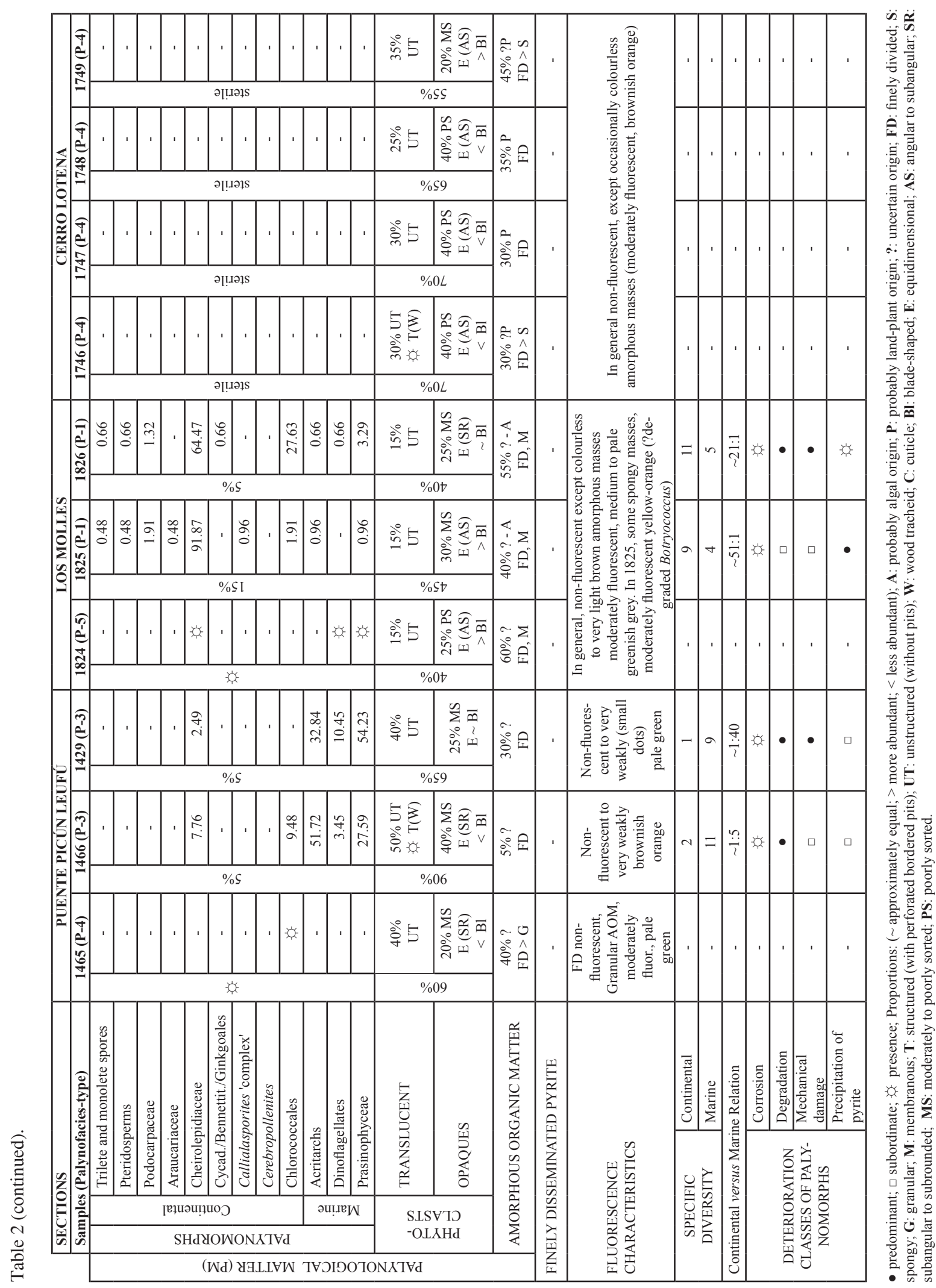


Palynomorphs were classified (based on their botanical affinities) in nine groups of continental origin: bryophytic/pteridophytic spores and pollen grains (Pteridospermopsida, Callialasporites 'complex', Cerebropollenites, Cheirolepidiaceae, Cycadales/Bennettitales/Ginkgoales, Araucariaceae and Podocarpaceae) of terrestrial origin and Botryococcus spp. (freshwater to brackish chlorococcalean algae) and three groups corrresponding to organic-walled marine microplankton (abbreviated in this paper to OWMM): acritarchs, dinoflagellate cysts and prasinophyte algae. A list of the palynomorph species identified is presented in Appendix 1. 200 palynomorphs for each sample were counted. Details of these statistical results were published in Martínez et al. (2005). Species diversity was analyzed for each palynological association with reference to the continental or marine palynomorph fraction.

The degree of alteration of the palynological assemblages (deterioration classes) was evaluated by examination of the preservation state of palynomorphs in sediment samples (Delcourt and Delcourt, 1980).

The palynofacies analysis presented here corresponds to a palyno-biolithofacies study according to Traverse (1994). The palynofacies of each study section with relative proportions of organic constituents, diversity (marine and continental), types of alteration and fluorescence characteristics are shown in table 2 and text-fig. 4.

\subsection{Total Organic Carbon Analysis}

Total organic carbon (TOC) analysis is the first step towards assessing the potential of a sediment to generate hydrocarbons. Combined with palynofacies data, the measurement of TOC in samples is a very useful parameter for evaluating the depositional environment and source rock potential (Tyson, 1995; Batten, 1996).

The current consensus concerning the minimum amount of active OC (organic carbon) needed for shales to become source rocks is $0.5-1 \%$ (Anders, 1991). However, not only the amount but also the type of organic matter is critical for evaluation of source rock potential. In this sense, Bordenave (in Tyson 1995) calculated that in order to produce enough hydrocarbons to fill $25 \%$ of the pore space in an illitic clay, $0.6 \%$ TOC for type I kerogen, $1 \%$
TOC for type II kerogen and 2.5\% TOC for type III kerogen is required.

All 20 outcrop samples from the five sections examined were analyzed for TOC at LANAIS N-15, CONICET-UNS, Agronomía, 8000 Bahía Blanca, Argentina (Text-fig. 5).

\subsection{Organic Matter Types And Preservation State}

Fluorescence properties of the PM are affected by the preservation state as well as the organic matter source (Tyson, 1984, 1990, 1995). Therefore, observation of all samples in blue light fluorescence was carried out, in order to classify the nature of unoxidized, thermally immature to mature oil source rocks. Well preserved amorphous organic matter (AOM) with a predominantly aquatic algal and bacterial origin shows a more intense fluorescence than material composed of land-derived aromatic (woody) structures (Bertrand, 1986; Tyson, 1995; Batten, 1996). Non-fluorescent amorphous material should not be assumed to be of terrestrial origin, especially when none of it fluoresces. In most marine sediments non-fluorescent amorphous material usually represents degraded plankton-derived AOM (Tyson, 1995). In this case, the cleaning up process of the palynological residue according to Batten (1981, 1996) and Batten and Morrison (1983) was followed to determine the affinity of the AOM. In addition, the quantity of woody or cuticular remains and miospores in the palynological preparation was determined.

Tyson's (1995, p. 347) qualitative scale of preservation based on fluorescence and type of PM was used herein. On this scale, high values (5-6) correspond to strongly fluorescent AOM, and the lowest values (1-2) characterize non-fluorescent inert material, oxidized or carbonized phytoclasts with few fluorescent palynomorphs and degraded plankton/bacteria-derived AOM.

Following Tyson (1995) and Batten (1996), for the evaluation of source rock potential, four types of kerogen/PM are differentiated. Type I kerogen corresponds to the highly oil-prone material, which consists of very strongly fluorescent organic matter corresponding to both, structured organic matter and AOM of algal/bacterial origin. Some resins and cuticles are included in this group. Type II kerogen corresponds to oil-prone material; fluorescent AOM 
is the most important constituent, but fluorescent palynomorphs, cuticle and membranous debris are also included. Type III kerogen corresponds to gas-prone material; this includes non-fluorescent and translucent structured phytoclasts, woody fragments, partially oxidized palynomorphs and plankton-derived material. Finally, type IV kerogen corresponds to the inert material; this includes non-fluorescent and opaque, strongly oxidized organic matter, such as opaque phytoclasts, fungal and chitinous material.

\subsection{Thermal Maturity}

The thermal maturity of the organic matter in the Los Molles Formation was determined using palynomorph colours (thermal alteration index or TAI of Staplin, 1969), especially those of psilate trilete spores (e.g., Deltoidospora and Dictyophyllidites) using the first slide made containing unoxidized PM. If these spores were not present in the palynological association (e.g., in marine associations) the TAI was obtained from the organic-walled microplankton (samples 1429 and 1466). However, the reliability of the results obtained is less certain because planktonic organisms do not react gradually to heat (Salas and Seiler, 1980). TAI was not determined for sterile or poorly preserved samples (Text-fig. 5).

\section{Results: Palynofacies-type}

Five types of palynofacies (P-1 to P-5) have been recognized (Plate 2). They are classified based on the relative frequencies of the four categories of PM mentioned above: palynomorphs, translucent and opaques phytoclasts and AOM. Their occurrences are indicated in table 2. Characteristic palynomorphs are illustrated on Plate 1, while the distribution of components of the PM is shown in text-fig. 4.

Palynofacies-type 1 (P-1). It has been identified in the Puesto Policía and Los Molles sections and is characterized by the highest proportion of palynomorphs (up to $20 \%$ of the total PM) of all studied palynofacies. Among the palynomorphs, those of continental origin are the dominant (up to $92 \%$ ) and exhibit a species diversity of 9-29 (mean diversity 19). The Cheirolepidiaceae, represented by Classopollis cf. C. classoides, C. torosus and C. simplex, is the most abundant group (41-92\%). Vitreisporites pallidus (Pterospermopsida group) average $10 \%$ of the total. The Callialasporites 'complex' ( $6 \%$ on average) is represented by $C$. turbatus, $C$. dampieri and $C$. segmentatus. Other groups of continental palynomorphs are less well represented, except the chlorococcalean algae Botryococcus which comprises, on average, $8 \%$ of the total population. The OWMM average $8 \%$ of the total palynomorphs and are mostly represented by acritarchs (Fillisphaeridium castaninum, $F$. densispinum, Micrhystridium cf. M. incospicuum, $M$. recurvatum, $M$. nannacanthum, M. fragile, Leiosphaeridia sp. E., L. sp. B, L. sp. cf. L. hyalina, Polygonium sp.). and prasinophytes such as Cymatiosphaera eupeplos, $C$. cf. $C$. volkheimerii and Pleurozonaria $\mathrm{cf}$. P. picunensis. Dinoflagellate cysts (Cleistosphaeridium sp. and Escharisphaeridia pocockii) are scarce (up to 2\%). The rest of the organic matter is constituted mainly by AOM (35-60\%), dominated by finely divided matter, with subordinate spongy and membranous matter. Under UV light it is non- to weakly fluorescent with colours varying from pale orange to pale green-grey, possibly derived mainly from land plants. However, in samples 1825, 1826, 1792, 1793 and 1795 the AOM consists of colourless spongy to granulate masses with a moderate to medium, pale greenish grey fluorescence, and is probably of algal origin. Among the opaque phytoclasts (20-35\%), those of equidimensional form are slightly more common than blade-shaped types. Unstructured fragments are dominant among the translucent phytoclasts (10-20\%). The lithofacies associated with P-1 consists of massive grey mudstones.

Palynofacies-type 2 (P-2). It is represented only in one sample from Puesto Policía section (1796). Palynomorphs and translucent phytoclasts constitute $10 \%$ each of the total organic matter. AOM makes up $45 \%$ of the total, represented by the finely divided fraction that dominates the association; it is non-fluorescent and easily removed after a short oxidation, and, hence, probably derived from vascular land plants. Scarce spongy masses are also found, with moderately fluorescence pale brownish-orange characteristics, perhaps representing degraded $\mathrm{Bo}$ tryococcus colonies. The opaque phytoclasts (35\%) are poorly sorted, small, equidimensional particles and large blade-shaped fragments, the latter being dominant. The ratio of continental to marine palynomorphs is 3 to 1, with Botryococcus predominating 
(nearly 58\%). Pteridosperms (5\%) and Cheirolepidiaceae $(4 \%)$ are subordinate. The OWMM reach values of approximately $28 \%$, with acanthomorph acritarchs dominating the group (Micrhystridium inconspicuum, M. fragile, Filisphaeridium castaninum, F. densispinum). Prasinophytes represented by Cymatiosphaera eupeplos comprise only $7 \%$ of the total OWMM. Dinoflagellate cysts amount to only $2 \%$ of the total. The lithofacies associated with this palynofacies P-2 is a massive medium grey siltstone.

Palynofacies-type 3 (P-3). It is found exclusively in samples from the Puente Picún Leufú section. Palynomorphs make up 5\% of the total PM. Among this group, OWMM are dominant (nearly 90\%) with a diversity of 9-11 species. Acritarchs, varying from $33 \%$ to $52 \%$ (Filisphaeridium balmei, Micrhystridium nannacanthum, $M$. recurvatum, $M$. cf. $M$. gregarium, Veryhachium valensii, Leiosphaeridia spp.) and prasinophytes varying from $28 \%$ to $54 \%$ (Cymatiosphaera eupeplos, C. cf. C. volkheimerii, Pleurozonaria cf. P. picunensis, Tasmanites sp.) are the most representative groups. Dinoflagellate cysts reach up to $10 \%$ of the total OWMM with only one taxon present (Escharisphaeridia pocockii). Palynomorphs of continental origin are scarce $(10 \%$ on average) and of low diversity (1 or 2 forms), mainly Cheirolepidiaceae (Classopollis simplex, Classopollis spp.) and Chlorococcales (Botryococcus spp.).

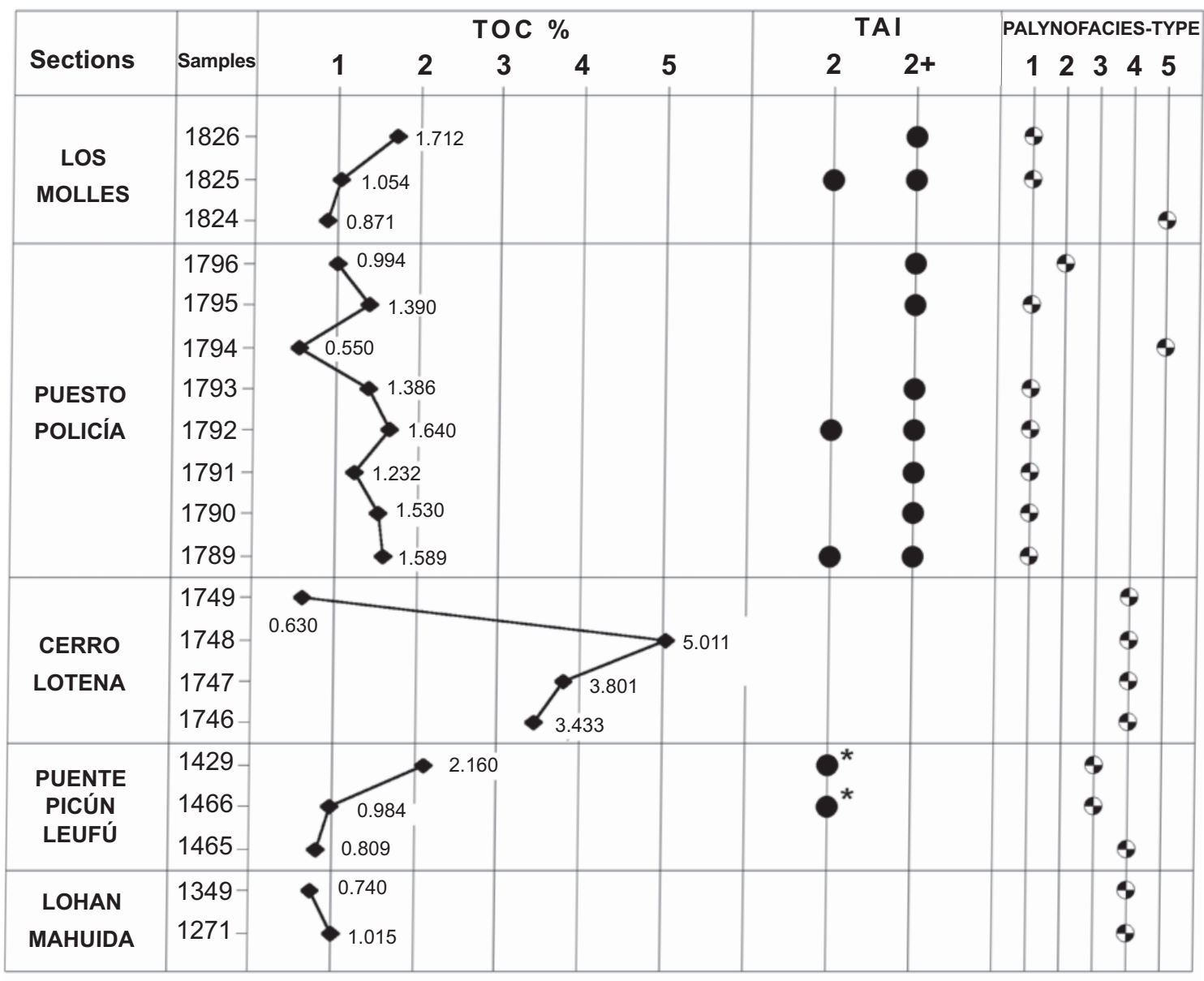

* measured on organic-walled marine microplankton

Text-fig. 5. Total organic carbon, thermal alteration index and palynofacies-type of the Los Molles Formation. 
The phytoclasts are four time more abundant than AOM. Translucent phytoclasts dominate this group (up to $50 \%$ ) with the unstructured type predominating. Opaque phytoclasts vary from $25 \%$ to $40 \%$, with blade-shaped types slightly more abundant than the equidimensional type. The AOM $(5-30 \%)$ is finely divided, non-fluorescent or with a weak brown-orange or pale green fluorescence. The lithofacies associated with this palynofacies is medium brown mudstones with bivalve remains and medium grey siltstones.

Palynofacies-type 4 (P-4). It is identified in several samples from the Cerro Lotena, Lohan Mahuida, and in a single sample from the Puente Picún Leufú section. Palynomorphs are very scarce; thus, they are expressed as 'present' (Table 2 and text-fig. 4). Classopollis major, C. spp., Callialasporites dampieri and Botryococcus spp. are the only identified forms. Bisaccate pollen grains, trilete spores and some undetermined proximate dinoflagellate cysts also occur, but they are very poorly preserved.

The ratio of phytoclasts to AOM is 3:1. Translucent, unstructured phytoclasts vary from $25 \%$ to $60 \%$. Opaque phytoclasts vary from $10 \%$ to $40 \%$, with the blade-shaped type dominating. The AOM $(30-45 \%)$ is represented mainly by the finely divided type, with the spongy type subordinate. It is mostly non-fluorescent but granular spongy or colourless masses show a weak to moderate fluorescence from greenish grey to brownish orange, suggesting a combined vascular land plant and algal origin. The associated lithofacies comprise siltstones and grey to medium brown mudstones with plant remains.

Palynofacies-type 5 (P-5). It is represented by one sample from each of the Los Molles and Puesto Policía sections. As for palynofacies P-4, palynomorphs are very scarce. Classopollis spp., Botryococcus spp., Tasmanaceae and indeterminate proximate dinoflagellate cysts are the only recognized forms.

$\mathrm{AOM}$ is the predominant organic matter (up to $70 \%$ ); it is mainly the spongy, membranous type and finely divided. After a short oxidation (no more than two minutes) hardly any amorphous matter was removed, so an algal origin is assumed following Batten (1981). Opaque phytoclasts vary from $15 \%$ to $25 \%$ of the total organic matter with the equidimensional type dominating over the blade-shaped types. The unstructured translucent phytoclasts make up $15 \%$ of the total PM. The lithofacies associated with palynofacies-type 5 are medium grey massive mudstones.

\section{Discussions}

\subsection{Paleoenvironmental and Paleoclimatical Interpretations}

As noted previously by several authors, such as Traverse (1994), Tyson (1995) and Batten (1996) many variables are involved in the deposition of palynological matter. Integration of sedimentary facies data with palynofacies may provide valuable information for a more accurate interpretation of depositional environments.

The proximal-distal terms, here used in the palynofacies analysis, derived from analogous concepts in sedimentology, dealing with lateral variations in sediment character with increasing distance from the siliciclastic sediment source (Tyson, 1995). Proximal facies, deposited near (or nearest) the fluvio-deltaic point source, show the greatest terrestrial influence.

In $\mathrm{P}-1$ the high percentages of continental palynomorphs (Cheirolepidiaceae) indicates varied and abundant vegetation associated with the shoreline. The episodically increased occurrence of Botryococcus may indicate the presence of fresh-brackish water bodies. The acanthomorph acritarchs with short spines (Micrhystridium 'complex') indicate higher energy marginal facies (Wall, 1965; Williams and Sarjeant, 1967; Sarjeant, 1974; Erkmen and Sarjeant, 1980; Tyson, 1993) dominate the group. The dominance of finely divided AOM reflects moderately oxidizing conditions with limited preservation of the other type of amorphous matter (Tyson, 1995, p. 170). The even distribution of opaque and translucent phytoclasts and the predominance of equidimensional over blade-shaped phytoclasts, indicates a short distance and/or relatively short duration of transport from the terrestrial source area (Tyson, 1995). Based on these observations, a proximal marine environment with moderate oxidizing conditions and energy is suggested. Sedimentary facies analysis has indicated a quiet subtidal environment where decantation predominates, probably in a zone between the off-shore shelf and a restricted part of the lower delta plain (Zavala, 1993).

In P-2 the association of Botryococcus and chiefly acanthomorph acritarchs, with subordinate prasinophytes suggests a marginal marine environment possibly influenced by fluvial discharge. Among the chlorophycean algae, Botryococcus is the most conspicuous freshwater taxon in recent marine palynomorph assemblages, usually being 
more abundant than marine dinoflagellates in sediments from shallow depths and below delta plumes (Matthiessen et al., 2000). The distribution of these freshwater algae in the marine environment is clearly related to the discharge of fresh water and suspended matter by rivers, and extends from the river mouths offshore into the shelf seas (Matthiessen et al., 2000). The dominance of blade-shaped opaque phytoclasts suggests a relatively distal position. According to several studies, the proportion of blade-shaped particles generally increases in an offshore or distal direction (Parry et al., 1981; Whitaker, 1984; Van der Zwan, 1990; Gorin and Steffen, 1991). Thus, the blade: equant frequency ratio of black phytoclast particles may be used in palynofacies studies to indicate proximal-distal variations.

In P-2, we observe that this ratio increases in a proximal direction. This discrepancy regarding the general model has also been observed by others, such as Frank and Tyson (1995), and may be related to the relative size of phytoclasts. Small, equidimensional phytoclasts are characteristic of distal deposits, whereas in proximal setting large, bladeshaped particles are quite abundant (Steffen and Gorin in Götz et al., 2003). In P-2, the dominance of large blade-shaped opaque particles compared to the small equidimensional clasts suggests proximal conditions. This interpretation is in accordance with that deduced by Zavala (1993), who reconstructed a shelf to pro-delta environment, from sedimentary facies analysis.

In P-3 a high proportion of marine over continental palynomorphs is recorded. The dominance of acritarchs and prasinophytes in association with proximate dinoflagellate cysts indicates a marginal marine environment with reduced salinity according to Prauss (1989, 1996, 2001); Prauss and Riegel (1989); Brocke and Riegel (1996), who consider that the succession dinoflagellates $\rightarrow$ acritarchs $\rightarrow$ prasinophytes reflects, respectively, a salinity gradient from open-marine of normal salinity to restricted marginal marine (near shore) of reduced salinity. The continental palynofloras reflect the vegetation of the coast with well drained soils in association with brackish to freshwater bodies. The other components of the PM, scarce finely divided $\mathrm{AOM}$ and translucent phytoclasts dominating over the opaque particles, suggest short distances and/or a short period of transport from the terrestrial source area (Tyson, 1995). The association of the organic matter present in P-3 suggests a restricted marine to inner neritic environment, with below normal mari- ne salinity conditions, close to the terrestrial source area. A coastal region of fresh- to brackish water bodies, connected by rivers to restricted marginalmarine environments, with sub-normal salinity as a consequence of high freshwater input, is envisaged. Zavala (1993) concluded that the lithofacies related to P-3 was deposited within a restricted shallow marine environment dominated by silt and clay sedimentation. He suggested an offshore shelf or a pro-delta environment.

Based on calcareous microfossils (foraminifers and ostracods) content, Ballent (2004) proposed similar environmental conditions, for the Los Molles Formation in Picún Leufú section, as suggested by the palynofacies-type 3 . The samples of P-3 coincide with the levels studied by Ballent for the middle to upper part of the Picún Leufú section. She proposed 'a shallow-marginal marine restricted environment, with clear and well oxygenated waters at the middle part of the section...', and 'low diversity of exclusively small agglutinated foraminifer towards the top of the section, suggests a restricted marginal environment, probably of reduced salinity and higher energy regime, than the underlying levels'. Thus, palynofacies data and calcareous microfossils enhance interpretations based solely on lithofacies analyses.

In P-4, the scarce palynomorph content, as well as the other types of PM, suggests a marine environment, close to the terrestrial source area (high terrestrial influx) under moderately oxidizing conditions. The lithofacies indicate different environmental conditions at each section (Zavala, 1993). At Cerro Lotena the siltstone samples are from to the basal 50 $\mathrm{m}$ of the section and reflect an evolution from shelf mudstones-prodelta to delta-front of a braided-delta system. The sedimentary facies recognized at Lohan Mahuida suggest the presence of a constructive form over a muddy bottom. For the Puente Picún Leufú section, the analyzed lithofacies (mudstone) suggests predominantly clay sedimentation in a quiet subtidal environment.

Finally, the scarce palynomorphs identified in P-5 indicate a land-plant association on the shore line and brackish or freshwater bodies under a marine-marginal of reduced salinity influence. Due to the scarce palynological content, this conclusions may be taken cautiously. The presence of mainly spongy and membranous AOM, suggests a non-marine provenance (Batten, 1983), probably derived from degraded Botryococcus colonies. The similar proportions of translucent and opaque phytoclasts, 
and the predominance of equidimensional types, indicate conditions very close to the terrigenous source area. Hence, a marine environment (probably marginal-marine) under dysoxic conditions, is suggested. According to sedimentological evidence Zavala (1993) interpreted a shelf environment.

The marginal-marine environment here suggested for some of the palynofacies-types coincides with a setting located along the boundary between the continental and the marine depositional realms. It is characterized by shallow water, marked variations in salinity depending upon river discharge and moderate to high energy of waves and currents (Boggs, 1987).

The presence of palynomorphs indicating different water and temperature conditions, as known from modern equivalents, has allowed us to draw some conclusions about the climatic conditions during the deposition of the Los Molles Formation. Among these taxa, Araucariaceae [Araucariacites and Inaperturopollenites (pars.)], Callialasporites 'complex', pteridophytic spores and pteridosperms indicate warm and humid climatic conditions; Podocarpaceae (Podocarpidites and Microcachryidites) suggest a temperate and relatively humid environment, and Cheirolepidiaceae (Classopollis), a termophilic taxa, indicates warm and dry (arid) conditions. Only the palynofacies associations with abundant spores and pollen grains were analyzed for this purpose, and relative frequencies of the suprageneric taxa were calculated to $100 \%$ (Text-fig. 4). A hypothetical reconstruction of the environment of the Los Molles Formation is suggested (Text-fig. 6) in which the Cheirolepidiaceae dominates well drained soils along the shore-line. The association of this termophilic plants with Araucariaceae, suggests warm and relatively humid conditions. Nearby the swamps or ponds on alluvial plains (locally more humid conditions) were the habitats for ferns and Cycadales/Bennettitales/Gingkgoales and pteridosperms. The Araucariaceae and Podocarpaceae represent upland communities. This model is in accordance with the reconstructions of several authors (García, 1998; Martínez, 1999; Martínez et al., 1999; Quattrocchio et al., 1996, 2001) for the Middle Jurassic, suggesting a warm and arid climate with locally moist conditions. The occurrence of organic-walled microplankton identified in samples from the Los Molles Formation, allows the reconstruction to be extended into the marine environment (Text-fig. 6).

\subsection{Source potential for hydrocarbons}

Within the Los Molles Formation the total organic carbon content varies between 0.550 and $5.011 \%$ for all the analyzed samples, with an average value of $1.624 \%$ (Text-fig. 5). This means that all of them are over the minimum value needed of OC $(0.5 \%)$, and $65 \%$ of the samples have TOC values of more than $1 \%$ needed for estimating the oil potential of the sample.

The spore colour for the examined samples varies between dark yellow and orange, suggesting a thermal alteration index (TAI) of 2 and 2+ according to the pollen/spore colour chart of Pearson (1990). These values are transitional between an immature phase and the window of liquid petroleum generation.

P-1, P-2 and P-5 show transitional characteristics between kerogen types II and III. The AOM is the main component of the organic matter (mean value of $50 \%$ ). A mixture of material of terrestrial origin and degraded plankton is assumed for this AOM. It is non- to very weakly fluorescent (preservation scale point $1 \mathrm{~b}$ to 3 ) and, less commonly, moderately fluorescent (scale point 4). Based on its TOC values (over 1\%) and given a mature TAI, P-1 is the only one, among these three palynofacies, that might suggest some potential for the generation of liquid hydrocarbons. However, the predominance, in P-1, P-2 and P-5 of finely disseminated amorphous organic matter (with scarce preservation of any other kind of AOM), the weak or non-fluorescent aspect and the scarcity or absence of pyrite in the samples, indicate moderately oxidizing conditions (Tyson, 1995), suggesting, in this case, the main conditioning factor to consider P-1 as an oil-prone material is related to the scarce preservation potential of the kerogen.

P-3 and P-4 show characteristics of type III kerogen and occasionally type IV, due to the predominant non-fluorescent, translucent and opaque phytoclasts. The scarce AOM is mainly assumed to be land plant derived. Some samples corresponding to P-4 (Cerro Lotena section: 1746, 1747 and 1748) exhibit TOC values over $3 \%$; thus, we suggest that they might have good gas-prone generative potential. Unfortunately the high proportion of opaque and/or dark translucent phytoclasts suggest oxidizing conditions, making questionable their generative potential. 


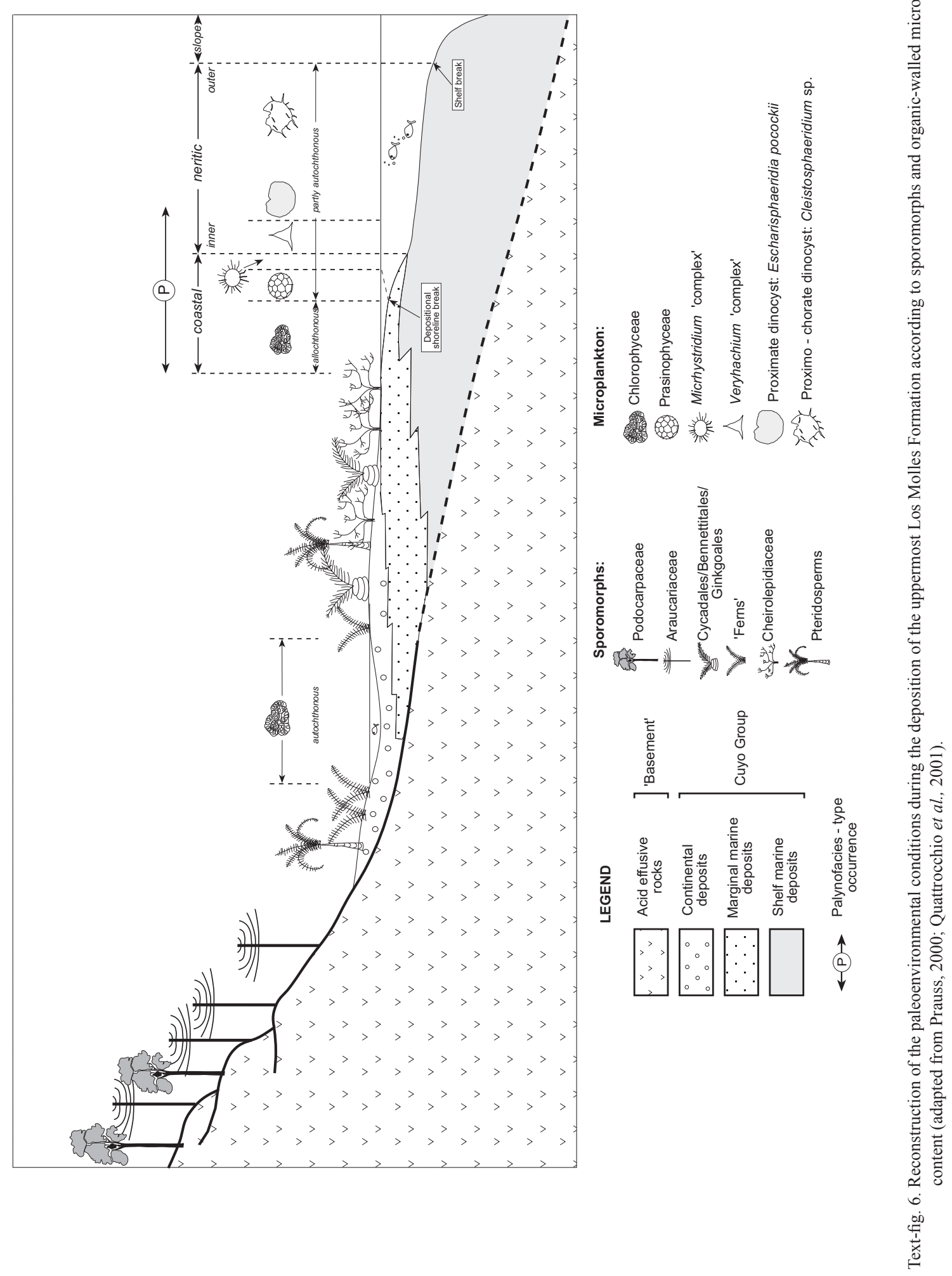




\section{Conclusions}

Palynofacies types identified in the uppermost Los Molles Formation allow us to confirm previous determinations of the marginal to partially restricted marine environmental conditions in the Neuquén Basin, during the deposition of the upper part of the Cuyo Group. This is in accordance with the results presented by García et al. (2000) for part of the basin, on the eastern side of Sierra de Chacaico. The Los Molles Formation is frequently claimed to represent a shelf pelitic to inner basin deposits. However, according to the results of our analysis, it is concluded that the paleoenvironment varied widely. For the central-south part of the basin, a restricted marine to inner neritic environment, close to the terrestrial source area, under moderately oxidizing conditions and hydrodynamic energy, is proposed. P-1 and P-4 are characterized by high terrestrial influx, thus a marine environment close to the terrestrial source area with moderate oxidizing conditions and energy is suggested. P-2 and P-3 show the highest proportion of microplankton. In P-2, the abundance of chlorococcalean freshwater algae (mainly Botryococcus) in association with chiefly acanthomorph acritarchs and subordinate prasinophytes suggest a marginal marine environment influenced by fluvial discharge. In P-3, the predominance of marine microplankton with different ecological requirements (salinity) reflects marine conditions ranging from a marginal-marine environment with sub-normal salinity, as a consequence of high freshwater input, to an inner neritic environment. In P-5, the characteristics of the AOM and the scarce palynomorphs identified suggest a marine environment (probably marginal-marine) under dysoxic conditions.

We conclude that the climate was warm (abundance of Cheirolepidiaceae, up to $92 \%$ ), but its association with Araucariaceae, suggest relatively humid conditions. Locally humid (with presence of swamps or ponds, on the alluvial plains) conditions are inferred during the deposition of the uppermost Los Molles Formation.

From the evaluation of multidisciplinary framework of TOC, TAI and kerogen type data of the uppermost Los Molles Formation it is suggested that this unit in the studied area, has some hydrocarbon potential. However, the state of the kerogen suggests that the anoxic-dysoxic conditions were not optimum for its preservation.

\section{Acknowledgements}

The authors thank D. Batten, S. Flint and an anonymous reviewer for their helpful suggestions which improved the final version of the manuscript. This work was supported by grants from the Consejo Nacional de Investigaciones Científicas y Técnicas (CONICET) and Secretaría General de Ciencia y Tecnología (SeCyT), Universidad Nacional del Sur.

\section{References}

Anders, D. 1991. Geochemical exploration methods. In Source and migration processes and evaluation techniques (Merrill, R.K.; editor). American Association of Petroleum Geologists: 89-95. Oklahoma.

Ballent, S.C. 2004. A micropalaeontological study of two Jurassic sequences in the Neuquén Basin, central-west Argentina. Ameghiniana 41 (3): 331-345.

Batten, D.J. 1981. Palynofacies, organic maturation and source potential for petroleum. In Organic maturation studies and fossil fuel exploration (Brooks, J.; editor). Academic Press: 201-223. New York.

Batten, D.J. 1983. Identification of amorphous sedimentary organic matter by transmitted light microscopy. In Petroleum Geochemistry and Exploration of Europe (Brooks, J.; editor). Geological Society of London, Special Publication 12: 275-287.

Batten, D.J. 1996. Palynofacies and palaeoenvironmental interpretation. In Palynology: Principles and applications (Jansonius, J.; McGregor, D.C.; editors). American Association of Stratigraphic Palynologists Foundation 3:1011-1064. Salt Lake City.

Batten, D.J.; Morrison, L. 1983. Methods of palynological preparation for palaeoenvironmental, source potential and organic maturation studies. In Palynology-Micropalaeontology: laboratories, equipment and methods (Costa, L.I.; editor). Bulletin of the Norwegian Petroleoum Directorate 2: 35-53.

Bertrand, R. 1986. Composition of potential oil from humic coals in relation to their petrographic nature. In Advances in organic geochemistry 1985 (Leythaeuser, D.; Rullkoter, D.; editors). Organic Geochemistry 10: 601-608.

Boggs, S. Jr. 1987. Principles of Sedimentology and Stratigraphy. Merrill Publishing Company: 784 p. Columbus, Ohio.

Brocke, R.; Riegel, W. 1996. Phytoplankton responses to shoreline fluctuations in the Upper Muschelkak (Middle Triassic) of Lower Saxony (Germany). Neues Jahrbuch für Geologie und Paläontologie, Abhandlungen 200: 53-73.

Burgess, P.; Flint, S.; Johnson, S. 2000. Sequence stratigraphic interpretation of turbiditic strata: an example from Jurassic strata of the Neuquén basin, Argentina. Geological Society of America Bulletin 112: 16501666.

Cruz, C.E.; Boll, A.; Gómez Omil, R.; Martínez, E.A.; Arregui, C.; Gulisano, C.; Laffitte, G.A.; Villar, H.J. 
2002. Hábitat de hidrocarburos y sistemas de carga Los Molles y Vaca Muerta en el sector central de la Cuenca Neuquina. Argentina. In Congreso de Exploración y Desarrollo de Hidrocarburos, No. 5, Actas CD-ROM: 20 p. Mar del Plata.

Delcourt, P.A.; Delcourt, H.R. 1980. Pollen preservation and Quaternary environmental history in the southeastern United States. Palynology 4: 215-231.

Erkmen, U.; Sarjeant, W.A.S. 1980. Dinoflagellate cysts, acritarchs and tasmanitids from the uppermost Callovian of England and Scotland: with a reconsideration of the 'Xanthidium pilosum' problem. Geobios 13: 45-99.

Frank, M.C.; Tyson, R.V. 1995. Parasequence-scale organic facies variations through an Early Carboniferous Yoredale cyclothem, Middle Limestone Group, Scremerston, Northumberland. Journal of the Geological Society, London 152: 41-50.

García, V.M. 1998. Reconstrucción paleoambiental en base a palinofacies de las Formaciones Los Molles, Lajas y Challacó (Jurásico medio) en la Sierra de Chacaico y adyacencias. Cuenca Neuquina. Provincia de Neuquén. Argentina. Ph.D. Thesis (Unpublished), Universidad Nacional del Sur, Departamento de Geología: 204 p. Bahía Blanca, Argentina.

García, V.M.; Quattrocchio, M.E.; Zavala, C.A. 2000. Estudio palinofacial del Grupo Cuyo, Jurásico medio en la Sierra de Chacaico. Parte 1. Formación Los Molles. In Simposio Argentino de Paleobotánica y Palinología, No. 11, Resúmenes: 32 p. Tucumán.

Gorin, G.E.; Steffen, D. 1991. Organic facies as a tool for recording eustatic variations in marine fine-grained carbonates-example of the Berriasian stratotype at Berrias (Ardèche, SE France). Palaeogeography, Palaeoclimatology and Palaeoecology 85: 303-320.

Götz, A.E.; Török, Á.; Feist-Burkhardt, S.; Konrád, G. 2003. Palynofacies patterns of the Middle Triassic ramp deposits (Mecsek Mts., S. Hungary). A powerful tool for high-resolution sequence stratigraphy. Mitteilungen Gesellschaft Geologie. Bergbaustud. Österreich 46: 77-90.

Groeber, P. 1946. Observaciones geológicas a lo largo del meridiano 70. 1. Hoja Chos Malal. Revista de la Asociación Geológica Argentina 1: 177-208.

Gulisano, C.A.; Gutiérrez Pleimling, A.R.; Digregorio, R.E. 1984. Esquema estratigráfico de la secuencia jurásica del oeste de la provincia del Neuquén. In Congreso Geológico Argentino, No. 9, Actas 1: 236259. Bariloche.

Hinterwimmer, G.A.; Jáuregui, J.M. 1984. Análisis de facies de los depósitos de turbiditas de la Formación Los Molles en el sondeo Barda Colorada Este, Provincia de Neuquén. In Congreso Geológico Argentino, No. 9 , Actas 5: 124-135. Bariloche.

Martínez, M.A. 1999. Palinología estratigráfica del Jurásico del centro-oeste de la Cuenca Neuquina. Ph.D. Thesis (Unpublished), Universidad Nacional del Sur, Departamento de Geología: 238 p. Bahía Blanca, Argentina.

Martínez, M.A. 2002. Palynological zonation of the Lajas Formation (Middle Jurassic) of the Neuquén Basin,
Argentina. Ameghiniana 39: 221-240.

Martínez, M.A.; García, V.M.; Quattrocchio, M.E. 1999. Análisis palinofacial aplicado a cortejos sedimentarios del Jurásico Medio en el sector suroccidental de la Cuenca Neuquina, Argentina. Revista Española de Paleontología 14 (2): 217-230.

Martínez,M.A.; Quattrocchio, M.E.; Sarjeant,W.A.S. 2001. Análisis palinoestratigráfico de la Formación Lajas, Jurásico Medio de la Cuenca Neuquina, Argentina. Revista Española de Micropaleontología 33: 31-58.

Martínez, M.A.; Quattrocchio, M.E.; Prámparo, M.B. 2005. Análisis palinológico de la Formación Los Molles, Grupo Cuyo, Jurásico medio de la cuenca Neuquina, Argentina. Ameghiniana 42 (1): 67-92.

Matthiesen, J.; Kunz-Pirrung, M.; Mudie, P.J. 2000. Freshwater chlorophycean algae in recent marine sediments of the Beaufort, Laptev and Kara Seas (Arctic Ocean) as indicators of river runoff. International Journal of Earth Sciences 89: 470-485.

Parry, C.C.; Whitley, P.J.K.; Simpson, R.D.H. 1981. Integration of palynological and sedimentological methods in facies of the Brent Formation. In Petroleum Geology of the Continental Shelf of North-West Europe (Illing, L.V.; Hobson, G.D.; editors). Heyden: 205-215. London.

Pearson, D.L. 1990. Pollen/spore color'standard'. 2nd. Edition. Phillips Petroleum Co. Bartlesville, Oklahoma.

Prámparo, M.B. 1989. Palinología estratigráfica del Cretácico de la Cuenca de San Luis. Ph.D. Thesis (Unpublished), Universidad Nacional de Río Cuarto: 243 p. Río Cuarto, Córdoba, Argentina.

Prauss, M. 1989. Dinozysten-Stratigraphie und Palynofazies im Obere n Lias und Dogger von NW-Deutschland. Palaeontographica B 214: 1-124.

Prauss, M. 1996. The Lower Toarcian Posidonia Shale of Grimmen, Northeast Germany. Implications from the palynological analysis of a near-shore section. Neues Jahrbuch für Geologie und Paläontologie, Abhandlungen 200: 107-132.

Prauss, M. 2000. The oceanographic and climatic interpretation of marine palynomorph phytoplankton distributiom from Mesozoic, Cenozoic and Recent sections. Göttinger Arbeiten zur Geologie und Paläontologie 76: $1-235$.

Prauss, M. 2001. Sea-level changes and organic-walled phytoplankton response in a Late Albian epicontinental setting, Lower Saxony basin, NW Germany. Palaeogeography, Palaeoclimatology, Palaeoecology 174: 221-249.

Prauss, M.; Riegel, W. 1989. Evidence from phytoplankton associations for causes of black shale formation in epicontinental seas. Neues Jahrbuch für Geologie und Paläontologie, Monanhefte. 1989, H 11: 671-682.

Quattrocchio, M.E. 1980. Contribución al conocimiento de la palinología estratigráfica del Jurásico Superior en la cuenca neuquina. Opera Lilloana 31: 1-59.

Quattrocchio, M.; Zavala, C.; García, V.; Volkheimer, W. 1996. Paleogeographic changes during the Middle Jurassic in the southern part of the Neuquén Basin, 
Argentina. In Advances in Jurassic Research (Riccardi, A.C.; editor). Transtec Publications, GeoResearch Forum 1-2: 467-484. Switzerland.

Quattrocchio, M.; García, V.; Martínez, M.; Zavala, C. 2001. A hypothetic scenario for the Middle Jurassic in the southern part of the Neuquén Basin, Argentina. In International Symposium on Mesozoic Terrestrial Ecosystems, No. 7, Asociación Paleontológica Argentina, Publicación Especial 7: 163-166. Buenos Aires.

Riccardi, A.C.; Gulisano, C.A. 1990. Unidades limitadas por discontinuidades, su aplicación al Jurásico Andino. Revista de la Asociación Geológica Argentina 45: 346-364.

Salas, A.; Seiler, J. 1980. Termopalinología: confiabilidad del método 'luz transmitida'. Primera parte. Boletín de la Asociación Latinoamericana de Paleobotánica y Palinología 7: 23-37.

Sarjeant, W.A.S. 1974. Fossil and Living Dinoflagellates. Academic Press: 182 p. London.

Staplin, F.L. 1969. Sedimentary organic matter, organic metamorphism, and oil and gas occurrence. Canadian Petroleum Geology, Bulletin 17 (1): 47-66.

Traverse, A. 1994. Sedimentation of organic particles. Cambridge University Press: 544 p.

Tyson, R.V. 1984. Palynofacies investigation of Callovian (Middle Jurassic) sediments from DSDP Site 534, Blake-Bahama Basin, western Central Atlantic. Marine and Petroleum Geology 1: 3-13.

Tyson, R.V. 1990. Automated transmitted light kerogen typing by image analysis: 1 . General aspects and program description. In Proceedings of the International Symposium on Organic Petrology, Ziest, 1990 (Fermont, W.J.J.; Weegink, J.W.; editors). Mededelingen Rijks Geologische Dienst 45: 139-150. The Netherlands.

Tyson, R.V. 1993. Palynofacies analysis. In Applied Micropalaeontology (Jenkins, D.J.; editor). Kluwer Academic Publishers: 153-191. Dordrecht, Holland.

Tyson, R.V. 1995. Sedimentary organic matter. Chapman \& Hall: 615 p. London.

Van der Zwan, C.J. 1990. Palynostratigraphy and palynofacies reconstruction of the Upper Jurassic to lowermost Cretaceous of the Draugen Field, offshore Mid Norway. Review of Palaeobotany and Palynology 62: 157-186.

Volkheimer, W. 1968. Esporas y granos de polen del Jurásico de Neuquén(RepúblicaArgentina). I. Descripciones sistemáticas. Ameghiniana 5: 333-370.

Volkheimer, W. 1972. Estudio palinológico de un carbón caloviano de Neuquén y consideraciones sobre los paleoclimas jurásicos de la Argentina. Revista del Museo de La Plata (nueva serie), Paleontología 6: 101-157.

Volkheimer, W. 1973. Palinología estratigráfica del Jurásico de la Sierra de Chacai Co y adyacencias (Cuenca Neuquina, República Argentina). I. Estratigrafía de las Formaciones Sierra Chacai Co (Pliensbachiano), Los Molles (Toarciano, Aaleniano), Cura Niyeu (Bayociano) y Lajas (Caloviano inferior). Ameghiniana
10: 105-131.

Volkheimer, W.; Quattrocchio, M. 1975. Palinología estratigráfica del Titoniano (Formación Vaca Muerta) en el área de Caichigüe(Cuenca Neuquina). ParteA: Especies terrestres. Ameghiniana 12: 193-241.

Volkheimer, W.; Melendi, D.L. 1976. Palinomorfos como fósiles guía ( $3^{\circ}$ parte). Técnicas del laboratorio palinológico. Revista minera de Geología y Mineralogía 34 (1-2): 19-30. Argentina.

Volkheimer, W.; Caccavari, M.A.; Sepúlveda, E. 1977. Datos palinológicos de la Formación Ortiz (Grupo La Amarga), Cretácico inferior de la Cuenca Neuquina (República Argentina). Ameghiniana 14: 59-74.

Wall, D. 1965. Microplankton, pollen, and spores from the Lower Jurassic in Britain. Micropaleontology 11: 151-190.

Weaver, C.E. 1931. Paleontology of the Jurasic and Cretaceous of West Central Argentina. University of Washington, Memoir 1: 1-469. Seattle.

Westermann, G.E.G.; Riccardi, A.C. 1979. Middle Jurassic ammonoid fauna and biochronology of the Argentine-Chilean Andes. II. Bajocian Stephanocerataceae. Palaeontographica A 164: 85-118.

Whitaker, M.F. 1984. The usage of palynology in definition of Troll Field geology. In Reduction of Uncertainties in Innovative Reservoir Geomodelling. In Offshore Northern Seas Conference and Exhibition, No. 6, Norsk Petroleums-forening, Paper G6: 44 p. Stavanger.

Williams, D.B.; Sarjeant, W.A.S. 1967. Organic-walled microfossils as depth and shoreline indicators. Marine Geology 5: 389-412.

Zavala, C.A. 1993. Estratigrafía y análisis de facies de la Formación Lajas (Jurásico medio) en el sector suroccidental de la Cuenca Neuquina. Provincia del Neuquén. República Argentina. Ph.D. Thesis (Unpublished), Universidad Nacional del Sur, Departamento de Geología: 259 p. Bahía Blanca, Argentina.

Zavala, C.A. 1996a. Sequence Stratigraphy in Continental to Marine Transitions. An Example from the Middle Jurassic Cuyo Group, South Neuquén Basin, Argentina. In Advances in Jurassic Research (Riccardi, A.C.; editor). Transtec Publications, GeoResearch Forum 1-2: 285-294. Switzerland.

Zavala, C.A. 1996b. High-Resolution Sequence Stratigraphy in the Middle Jurassic Cuyo Group, South Neuquén Basin, Argentina. In Advances in Jurassic Research (Riccardi, A.C.; editor). Transtec Publications, GeoResearch Forum 1-2: 295-304. Switzerland.

Zavala, C.; González, R. 2001. Estratigrafía del Grupo Cuyo (Jurásico Inferior-Medio) en la Sierra de la Vaca Muerta, Cuenca Neuquina. Boletín de Informaciones Petroleras 65: 40-54. Buenos Aires.

Zumberge, J.E. 1993. Organic geochemistry of Estancia Vieja oils, Río Negro norte block. In Organic geochemistry (Engel, M.H.; Macko, S.A.; editors). Plenum Press: 461-471. New York. 
PLATES 1-2 


\section{PLATE 1}

Scale bars represent $10 \mu \mathrm{m}$.
A Deltoidospora australis (Couper) Pocock, 1970; UNSP PP 1789c: P12.
B Dictyophyllidites mortoni (de Jersey) Playford and Dettmann, 1965; UNSP PP 1795c: C57.
C Rugulatisporites neuquenensis Volkheimer, 1973; UNSP PP 1793c: T47/3.
D Antulsporites saevus (Balme) Archangelsky and Gamerro, 1966; UNSP PP 1789c: W10.
E Klukisporites labiatus (Volkheimer) Baldoni and Archangelsky, 1983; UNSP PP 1789c: V44/3.
F Tetrad of Classopollis intrareticulatus Volkheimer, 1972; UNSP PP 1795c: T19/2.
G Callialasporites dampieri (Balme) Dev, 1961; UNSP PP 1795c: C49/3.
H Callialasporites turbatus (Balme) Schulz, 1967; UNSP PP 1789c: T62/2.
I Callialasporites segmentatus (Balme) Srivastava, 1963; UNSP PP 1789c: J15.
J Microcachryidites castellanosii Menéndez, 1968; UNSP PP 1793c: F58/3.
K Podocarpidites cf. P. ellipticus Cookson, 1947; UNSP PP 1789c: X27/3.
L Vitreisporites pallidus (Reissinger) Nilsson, 1958; UNSP PP 1789c: J44.
M Micrhystridium inconspicuum (Deflandre) Deflandre, 1937; emend. Deflandre and Sarjeant 1970, UNSP PP 1796c: $\mathrm{O} 20 / 1$.
N Micrhystridium fragile Deflandre, 1947; UNSP PP 1796c: S54/3.
O Veryhachium valensii (Valensi) Downie and Sarjeant, 1965; UNSP PL 1429a: G30.
P Filisphaeridium castaninum (Valensi, 1953) Sarjeant and Stancliffe, 1994; UNSP PP 1793c: E57/2.
Q Filisphaeridium densispinum (Valensi, 1953) Sarjeant and Stancliffe, 1994; UNSP PP 1796c: O53/4.
R Cymatiosphaera sp. 1 (in Martínez et al., 2005); UNSP PL 1466a: 9,4/137,2.
S Cymatiosphaera sp. 2 (in Martínez et al., 2005); UNSP PL 1466a: W59/4.
T Cymatiosphaera cf. C. volkheimerii (Quattrocchio) Martínez et al., 2005; UNSP PL 1429CAN: P39/1.
U Polygonium sp. cf. ? P. jurassicum Bucefalo Palliani, Riding and Torricelli, 1996; UNSP PP 1792c: F45/3.
V Tasmanites sp. (in Martínez et al., 2005); UNSP PL 1429a: C32.
W Pleurozonaria cf. P. picunensis Quattrocchio, 1980 (in Martínez et al., 2005); UNSP PL 1429a: K25/1.
X Escharisphaeridia pocockii (Sarjeant) Erkmen and Sarjeant, 1980; UNSP PL 1429c: L18/3.
Y Cleistosphaeridium sp.; UNSP PP 1793c: V41/3. 

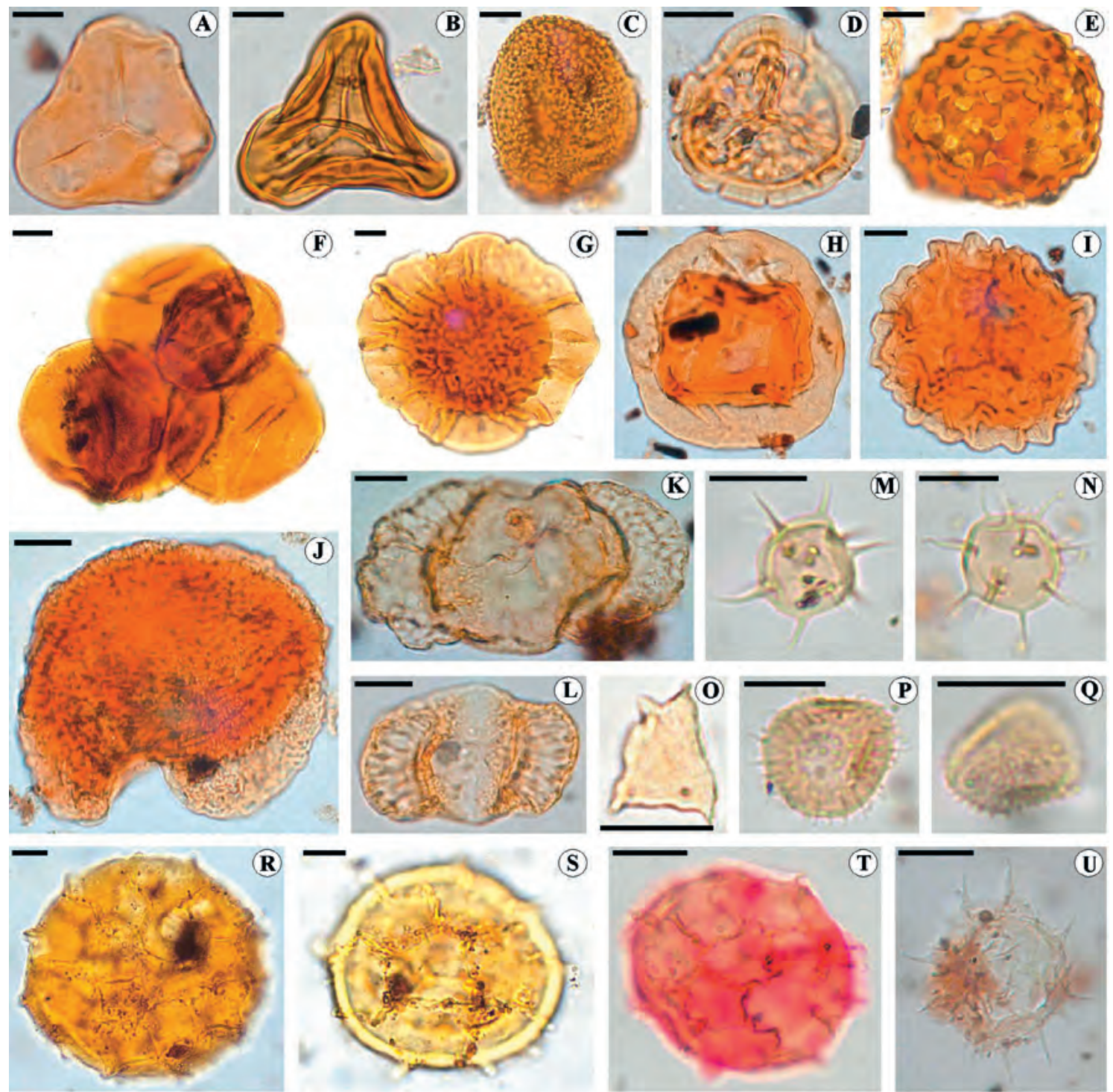

(S)
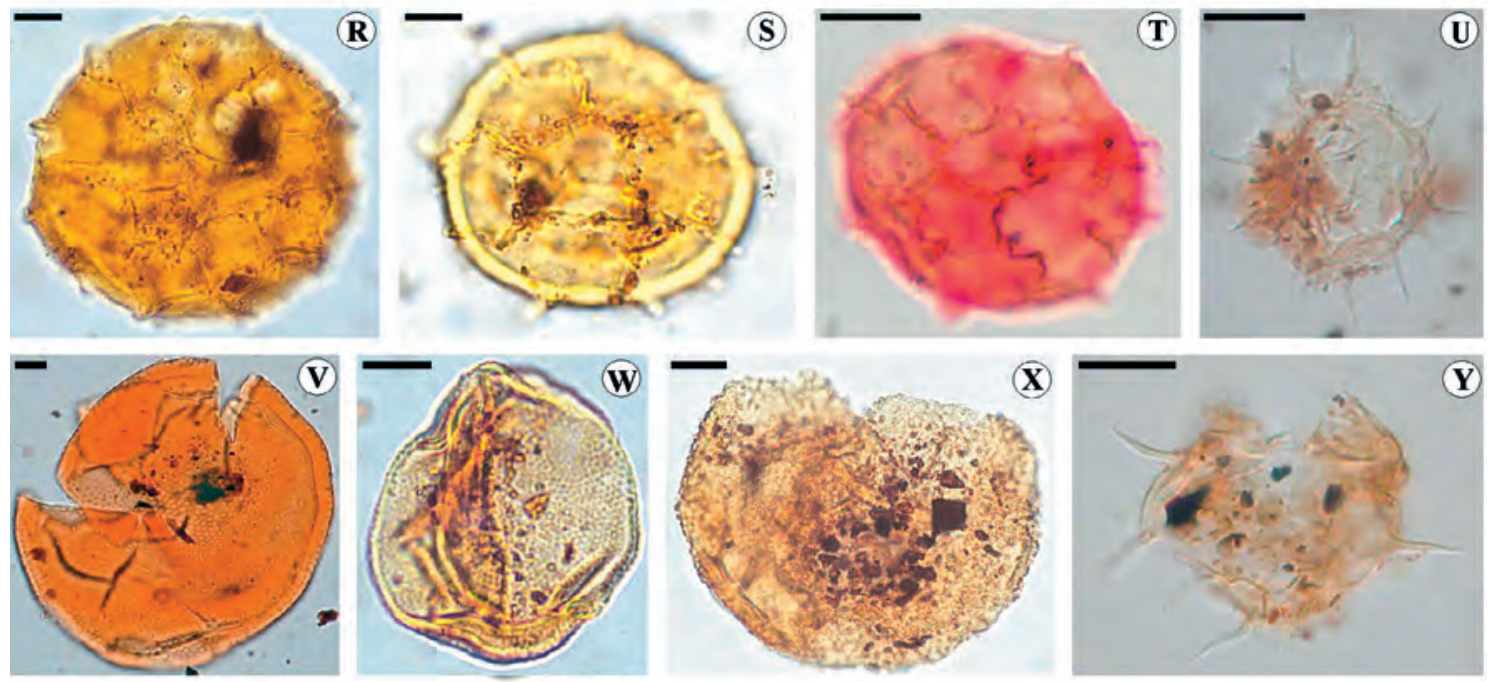


\section{PLATE 2}

Scale bars represent $10 \mu \mathrm{m}$

A-B Palynofacies-type 4, before and after cleaning up process (brief ultrasonic and/or two minutes with oxidative treatment), sample UNSP CL 1746, BOP: blade-shaped opaque phytoclast, SP: structured phytoclast (with perforated pits).

C-D Palynofacies-type 2, before and after cleaning up process, sample UNSP PP 1796, DBot: degraded Botryococcus, Bot: well-preserved colonies of Botryococcus.

E Well-preserved colonies of Botryococcus, UNSP PP 1796c: P16.

F-G Palynofacies-type 5, before and after cleaning up process, sample UNSP PP 1794, AOM: amorphous organic matter.

H Palynofacies-type 3, sample UNSP PL 1466, Pr: prasinophyte.

I Palynofacies-type 1, sample UNSP M 1825, Pal: indeterminate palynomorph, EOP: equidimensional opaque phytoclast. 

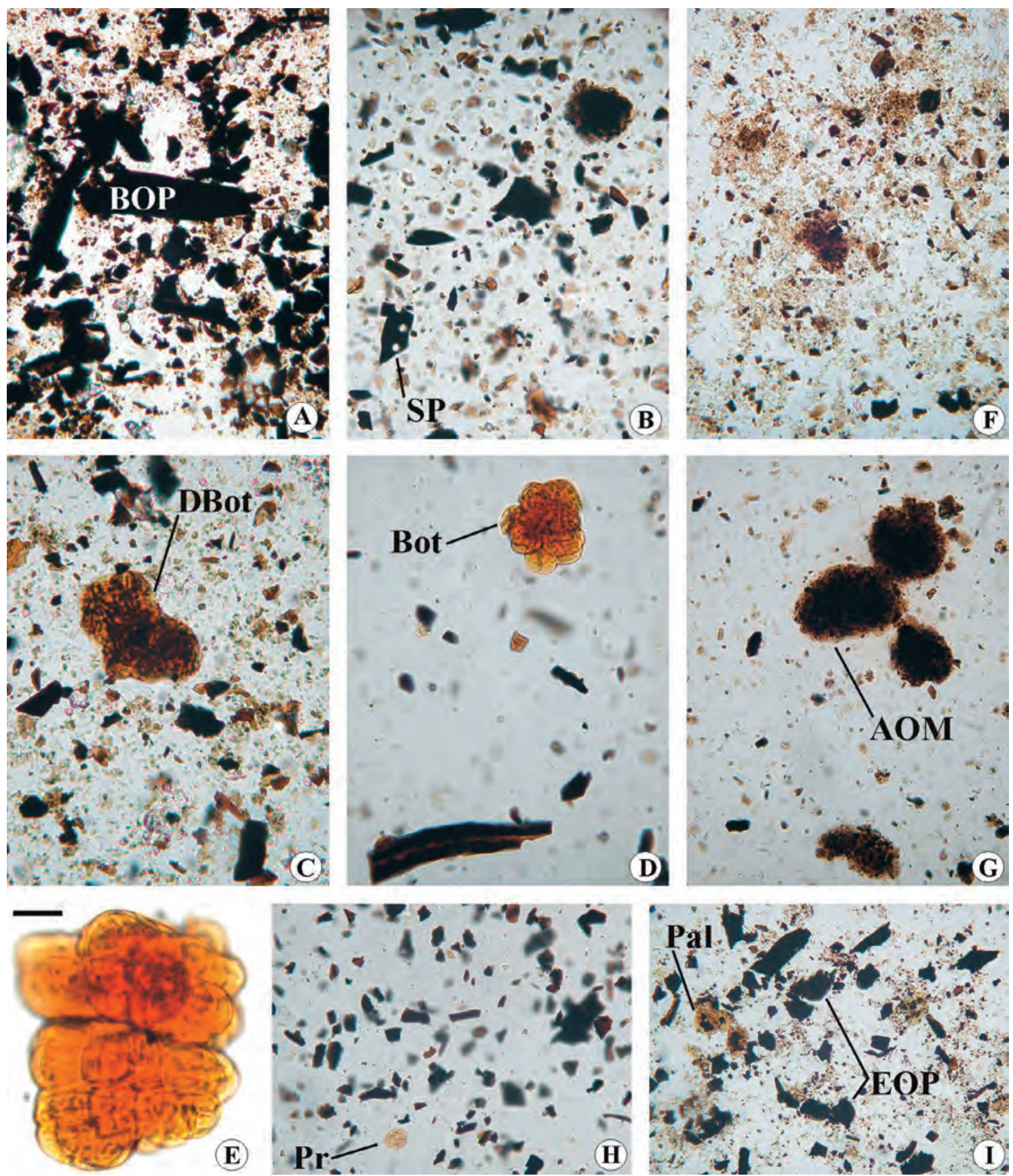


\section{APPENDIX 1: SPECIES LIST.}

\section{Sporomorphs}

\section{Pteridophytic and bryophytic spores}

Antulsporites saevus (Balme) Archangelsky and Gamerro, 1966 (Plate 1.D) Antulsporites varigranulatus (Levet-Carette) Reiser and Williams, 1969

Auritulinasporites spp.

Biretisporites spp.

? Camptozonotriletes sp. 1 (in Martínez et al., 2001)

Clavatisporites cf. C. bagualensis (Volkheimer) Martínez et al., 2001

Deltoidospora australis (Couper) Pocock, 1970 (Plate 1.A)

Deltoidospora minor (Couper) Pocock, 1970

Deltoidospora neddeni Pflug, 1953

Deltoidospora spp.

Dictyophyllidites mortoni (de Jersey) Playford and Dettmann, 1965 (Plate 1.B)

Dictyophyllidites spp.

Divisisporites sp. (in Martínez et al., 2005)

Gleicheniidites spp.

Klukisporites labiatus (Volkheimer) Baldoni and Archangelsky, 1983 (Plate 1.E)

Klukisporites variegatus Couper, 1958

Klukisporites spp.

Leptolepidites spp.

Nevesisporites $\mathrm{cf}$. N. radiatus (Chlonova) Srivastava, 1972

Punctatosporites scabratus (Couper) Norris, 1965

Retitriletes spp.

Rugulatisporites neuquenensis Volkheimer, 1972 (Plate 1.C)

Verrucosisporites varians Volkheimer, 1972

Verrucosisporites spp.

spore gn. et sp. indet. (in Martínez et al., 2005)

\section{Gymnosperm pollen}

Alisporites spp.

Araucariacites australis Cookson, 1947

Araucariacites fissus Reiser and Williams, 1969

Araucariacites pergranulatus Volkheimer, 1968

Callialasporites dampieri (Balme) Dev, 1961 (Plate 1.G)

Callialasporites microvelatus Schulz, 1966

Callialasporites segmentatus (Balme) Srivastava, 1963 (Plate 1.I)

Callialasporites trilobatus (Balme) Dev, 1961

Callialasporites turbatus (Balme) Schulz, 1967 (Plate 1.H)

Callialasporites sp. (in Martínez et al., 2005)

Callialasporites spp.

Cerebropollenites macroverrucosus (Thiergart), Schulz 1967

Cerebropollenites cf. C. macroverrucosus (Thiergart) Schulz, 1967

Classopollis cf. C. classoides (Pflug) Pocock and Jansonius, 1961

Classopollis intrareticulatus Volkheimer, 1972 (Plate 1.F)

Classopollis itunensis Pocock, 1962

Classopollis major Groot and Groot, 1962

Classopollis simplex (Danzé, Corsin and Laveine) Reiser and Williams, 1969

Classopollis torosus (Reissinger) Burger, 1965

Classopollis cf. C. torosus (Reissinger) Burger, 1965 (in Volkheimer, 1968)

Classopollis spp.

Cycadopites adjectus (de Jersey) Volkheimer and Quattrocchio, 1975 
Cycadopites cf. C. adjectus (de Jersey) Volkheimer and Quattrocchio, 1975

Cycadopites nitidus (Balme) de Jersey, 1964

Cycadopites spp.

Inaperturopollenites indicus Srivastava, 1966

Inaperturopollenites microgranulatus Volkheimer, 1972

Inaperturopollenites spp.

Microcachryidites castellanosii Menéndez, 1968 (Plate 1.J)

Monosulcites sp. A (in Volkheimer, 1972)

Monosulcites sp. cf. M. sp. B (in Volkheimer and Quattrocchio, 1975)

Monosulcites spp.

Phrixipollenites sp.

Podocarpidites cf. P. ellipticus Cookson, 1947 (Plate 1.K)

Podocarpidites spp.

Vitreisporites pallidus (Reissinger) Nilsson, 1958 (Plate 1.L)

\section{Organic-walled microplankton}

\section{Chlorococcales and Prasinophyceae algae}

\section{Botryococcus spp.}

Cymatiosphaera eupeplos (Valensi) Deflandre, 1954

Cymatiosphaera cf. C. eupeplos (Valensi) Deflandre, 1954

Cymatiosphaera cf. C. volkheimerii (Quattrocchio) Martínez et al., 2005 (Plate 1.T)

Cymatiosphaera sp. 1 (in Martínez et al., 2005) (Plate 1.R)

Cymatiosphaera sp. 2 (in Martínez et al., 2005) (Plate 1.S)

Cymatiosphaera sp. 3 (in Martínez et al., 2005)

Cymatiosphaera 'complex'

Pleurozonaria cf. P. picunensis Quattrocchio, 1980 (in Martínez et al., 2005) (Plate 1.W)

Pleurozonaria spp.

Tasmanites sp. (in Martínez et al., 2005) (Plate 1.V)

\section{Dinoflagellates}

Cleistosphaeridium sp. (Plate 1.Y)

Escharisphaeridia pocockii (Sarjeant) Erkmen and Sarjeant, 1980 (Plate 1.X)

\section{Acritarchs}

Baltisphaeridium sp. (in Martínez et al., 2005)

Filisphaeridium balmei (Sarjeant, 1973) Sarjeant and Stancliffe, 1994

Filisphaeridium cf. F. balmei (Sarjeant, 1973) Sarjeant and Stancliffe, 1994

Filisphaeridium castaninum (Valensi, 1953) Sarjeant and Stancliffe, 1994 (Plate 1.P)

Filisphaeridium densispinum (Valensi, 1953) Sarjeant and Stancliffe, 1994 (Plate 1.Q)

Leiosphaeridia sp. B (in Volkheimer et al., 1977)

Leiosphaeridia sp. E (in Prámparo, 1989)

Leiosphaeridia cf. L. sp. F (in Prámparo, 1989)

Leiosphaeridia sp. cf. L. hyalina (Deflandre) Downie, 1957 (in Quattrocchio, 1980)

Leiosphaeridia spp.

Micrhystridium brevispinosum (Sarjeant) Sarjeant and Stancliffe, 1994

Micrhystridium echinoides cf. M. echinoides forma minor Valensi, 1953

Micrhystridium fragile Deflandre, 1947 (Plate 1.N)

Micrhystridium cf. M. gregarium Sarjeant, 1973

Micrhystridium inconspicuum (Deflandre) Deflandre, 1937; emend. Deflandre and Sarjeant, 1970 (Plate 1.M)

Micrhystridium cf. M. inconspicuum (Deflandre) Deflandre, 1937; emend. Deflandre and Sarjeant ,1970 (in Martínez et al., 2005)

Micrhystridium nannacanthum Deflandre, 1945

Micrhystridium recurvatum Valensi, 1953

Micrhystridium spp.

Polygonium sp. cf. ? P. jurassicum Bucefalo Palliani, Riding and Torricelli, 1996 (Plate 1.U)

Polygonium sp. (in Martínez et al., 2005)

Veryhachium valensii (Valensi) Downie and Sarjeant, 1965 (Plate 1.O) 